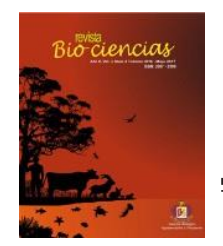

\title{
Hydrography of the entrance to the Gulf of California: The upper limit of the oxygen minimum
}

\section{Hidrografía de la entrada al Golfo de California: La frontera superior del mínimo de oxígeno}

\author{
Ruelas Tolentino, J.A. ${ }^{1}$, Trasviña Castro, $A .{ }^{2}$. \\ 'Universidad Autónoma de Baja California Sur. Carretera al Sur km 5.5. La Paz, B.C.S., C.P.23080, México. \\ ${ }^{2}$ Centro de Investigación Científica y de Educación Superior de Ensenada (CICESE), \\ Unidad La Paz, Miraflores No. 334 e/Mulegé y La Paz, La Paz CP 23050, Baja California Sur, México.
}

\begin{abstract}
A B S T R AC T
At the entrance to the Gulf of California three surface waters converge: California Current, Tropical Surface and Gulf of California water masses. Historical data includes observations of 10 cruises between 1991 and 2011. The Gulf of California water mass does not appear to have a significant presence at the entrance, we only found it at the northern end of the entrance. The water of the California Current is typically found at the surface but in this region it is often at about $50 \mathrm{~m}$ depth, below the Surface Tropical Water mass. In contrast, the Subtropical Subsurface Water is often very close to the surface and because of this, the oxygen minimum is also shallower. The confluence of water masses at the entrance of the gulf results in changes in vertical composition between oceanic and coastal regions. In the oceanic region we find two water masses (Tropical Superficial and California Current) above the oxygen minimum. Whereas near the coastal the oxygen minimum occurs immediately below the Tropical Surface water mass. However, the stratification here is more
\end{abstract}

Article Info/Información del artículo

Received/Recibido: April $4^{\text {th }} 2016$.

Accepted/Aceptado: March $1^{\text {st }} 2017$.
RES U M E N

En la entrada al Golfo de California confluyen tres masas de agua superficiales: Corriente de California, Superficial Tropical y del Golfo de California. Los datos históricos incluyen observaciones de 10 cruceros entre 1991 y 2011. La masa de agua del Golfo de California no tiene una presencia importante en la entrada y solo en el extremo norte de la entrada encontramos su influencia. El agua de la Corriente de California es superficial pero en esta región a menudo se le encuentra a $50 \mathrm{~m}$, por debajo del Agua Tropical Superficial. En contraste, el Agua Subsuperficial Subtropical se encuentra con frecuencia muy cerca de la superficie y debido a esto también es más somero el mínimo de oxígeno. La confluencia de masas de agua en la entrada al Golfo de California resulta en cambios en composición vertical entre la región más oceánica y la más costera. En la región oceánica encontramos dos masas de agua superficiales (Tropical Superficial y Corriente de California) por encima del mínimo de oxígeno. $Y$ en la zona costera en la superficial solo hay Tropical Superficial y el mínimo de oxígeno esta inmediatamente abajo de esta agua superficial. Sin embargo la estratificación es más intensa aquí que en el océano abierto, y esto dificulta la mezcla y el afloramiento de valores de oxígeno bajos. En esca-

*Corresponding Author:

Armando Trasviña Castro, Centro de Investigación Científica y de Educación Superior de Ensenada (CICESE), Unidad La Paz, Miraflores No. 334 e/Mulegé y La Paz, La Paz CP. 23050, Baja California Sur, México, Phone: +52(612) 1213 031, 28103. E-mail.:trasvi@cicese.mx 
intense than in the open ocean hindering the mixing of low oxygen values with the surface. At smaller scales, the density surfaces limiting with the layer of oxygen minimum are influenced by the mesoscale structures in the region. They deepen/rise below the hot/cold-core eddies and rise close to the surface under coastal currents.

\section{K E Y W O R D S}

Mexican eastern tropical Pacific, oxygen minimum zone, hydrography, deep chlorophyll maximum, Gulf of California.

\section{Introduction}

The entrance region to the Gulf of California is found in the northern transition of the Oriental Tropical Pacific (PATO). Herein three water massesconcur (Lavin et al., 2006): water of the California Current (Kessler, 2006; Castro, et al., 2006; Wyrtki, 1967), tropical superficial water (TSW) and saline superficial water from the California Gulf (GCW). The characteristics of these water masses are enlisted in Table 1. The confluence results in changing conditions that generate mesoscale processes (eddies, filaments) able to generate exchange, mixing and that work to agregate or disperse the plankton communities. In addition, within the first $150 \mathrm{~m}$ of the water column there is the presence of a maximum subsuperficial of chlorophyll fluorescence (DMC) and in the upper limit of the oxygen minimum zone (ZMO). So far, there has not been well understanding on the variability space-temporal of these characteristics, neither its relation with dynamic aspects (Cepeda-Morales, et al., 2009). It is important to notice that the recent article by Portela, et al., (2016) modifies the classification of the water masses in the Mexican Pacific. These authors widen the ranges of the California Current water and Tropical Superficial Waters; nevertheless, the limits we use in this work are still valid at the entrance of the California Gulf, and are within the new limits proposed by these authors.

It is in the upper layers of the Calfornia Gulf entrance where the most active communication with the adjacent Pacific Ocean was carried. Superficial circulation here is more complex due to the confluence of superficial waters with very dissimilar characteristics (Griffiths, 1968; Alvarez-Sanchez, et al., 1978; Castro, et al., 2000; las más pequeñas las superficies isopícnicas que limitan con el mínimo de oxígeno son influenciadas de manera muy importante por las estructuras de mesoescala en la región. Se profundizan/elevan por debajo de los remolinos de núcleo cálido/frío y se elevan hasta muy cerca de la superficie por debajo de corrientes costeras.

\section{P A L A B R A S C L A V E}

Pacífico Tropical Oriental Mexicano, mínimo de oxíge--no, hidrografía, profundidad del máximo de clorofila, Golfo de California.

\section{Introducción}

La región de la entrada al Golfo de California se encuentra en transición norte del Pacífico Tropical Oriental (PATO). Aquí concurren tres masas de agua (Lavín, et al., 2006): el agua de la Corriente de California (Kessler, 2006; Castro, et al., 2006; Wyrtki, 1967), el agua tropical superficial (TSW, por sus siglas en inglés) y el agua superficial salina del Golfo de California (GCW). Las características de estas masas de agua se enlistan en la Tabla 1. La confluencia da como resultado condiciones cambiantes que generan procesos de mesoescala (remolinos, filamentos) capaces de generar intercambio, mezcla y que sirven para agregar o dispersar las comunidades planctónicas. Además dentro de los primeros 150 $\mathrm{m}$ de la columna de agua se encuentra la presencia de un máximo subsuperficial de fluorescencia de la clorofila (DMC por sus siglas en inglés), y el límite superior de la zona del mínimo de oxigeno (ZMO). Hasta ahora no se ha comprendido bien la variabilidad espacio-temporal de estas características, ni su relación con aspectos dinámicos (Cepeda-Morales, et al., 2009). Es importante notar que el artículo reciente de Portela, et al., (2016) modifica la clasificación de las masas de agua del Pacífico Mexicano. Estos autores amplían los rangos del agua de la Corriente de California y de las aguas Tropicales Superficiales; sin embargo, los límites que usamos en este trabajo siguen siendo válidos en la entrada al Golfo de California y están dentro de los nuevos límites propuestos por estos autores.

Es en las capas superiores de la entrada al Golfo de California donde se lleva a cabo la comunicación más activa con el Océano Pacífico adyacente. La circulación superficial aquí es muy compleja debido a la confluencia de aguas superficiales con características muy disímiles (Griffiths, 1968;Álvarez-Sánchez, 
Lavin, et al., 2003). Table 1 shows properties of the different water masses.

The high concentration of dissolved oxygen (DO) close to the surface is due to the exchange of gas with the atmosphere, to the processes of the mixing mix in the superior ocean and the production of oxygen by the phytoplankton. As depth increases, respiration and other processes consume dissolved oxygen that decreases it to the values closest to zero, making the survival of aerobic organisms difficult. Under the oxygen minimum, different masses of intermediate and depth water masses provide oxygen and physic-chemical properties according to its formation site. The organisms that inhabit at great depths have physiological adaptations to survive in almost anoxic environments (Serrano and Hendrickx, 2010). In this sense, it is a physiological barrier that obstructs contact between faunas that live above and under the Oxygen Minimum Zone (OMZ) (Diaz and Rosenberg, 1995; Helly and Levin, 2004; Hendrickx and Serrano, 2010). There are regions in the coastal strip of the California Gulf and the Coast of Jalisco to Chiapas where the availability of fishery resources is reduced due to the presence of a shallow OMZ (Hendrickx and Serrano, 2010).

The East Pacific is characterized by presenting a very wide OMZ that covers from Alaska to Chile. However, the entrance to the Gulf of California is one of the places where the depth of oxygen minimum is very shallow $(\mathrm{Ce}$ peda-Morales et al., 2013). In some areas, the OMZ is found at only $50 \mathrm{~m}$ depth. et al., 1978; Castro, et al., 2000; Lavín, et al., 2003). La Tabla 1 muestra las propiedades de las diferentes masas delagua.

La alta concentración del oxígeno disuelto (OD) cercana de la superficie se debe al intercambio de gases con la atmósfera, a los procesos de mezcla turbulenta en el océano superior y a la producción de oxígeno por el fitoplancton. Conforme aumenta la profundidad, la respiración y otros procesos consumen el oxígeno disuelto que lo disminuye hasta valores muy cercanos a cero, dificultando la supervivencia de organismos aeróbicos. Por debajo del mínimo de oxígeno las diferentes masas de aguas intermedias y profundas aportan oxígeno y propiedades fisicoquímicas acordes con su sitio de formación. Los organismos que habitan a grandes profundidades tienen adaptaciones fisiológicas para sobrevivir en ambientes casi anóxicos (Serrano y Hendrickx, 2011). En este sentido es una barrera fisiológica que obstaculiza el contacto entre las faunas que viven por arriba y por debajo de la ZMO (Díaz y Rosenberg, 1995; Helly y Levin, 2004; Hendrickx y Serrano, 2010). Hay regiones de la franja costera del Golfo de California y de la costa de Jalisco hasta Chiapas donde la disponibilidad de recursos pesqueros es reducida debido a la presencia de una zona de mínimo oxígeno (ZMO) somera (Hendrickx y Serrano, 2010).

El Pacífico Oriental se caracteriza por presentar una ZMO muy amplia que abarca desde Alaska hasta Chile. Sin embargo, la entrada al Golfo de California es uno de los lugares donde la profundidad del mínimo de oxígeno es muy somera (Cepeda-Morales et al., 2013). En algunas zonas, la ZMO se encuentra a solo $50 \mathrm{~m}$ de profundidad.

El objetivo de este trabajo consiste en describir la hidrografía en la entrada al Golfo de California, haciendo hin-

Table 1.

Properties of the water masses in the Gulf of California, according to Lavin et al., (2009)

Tabla 1.

Propiedades de las masas de agua del Golfo de California, según Lavín et al., (2009)

\begin{tabular}{lccc}
\hline \multicolumn{1}{c}{ Water Masses } & Abbreviation & Salinity Range & $\begin{array}{c}\text { Temperature Range } \\
\left({ }^{\circ} \mathrm{C}\right)\end{array}$ \\
\hline Water of the Gulf of California. & GCW & $>34.9$ & $\geq 12$ \\
Tropical Surface Water. & TSW & $<34.9$ & $\geq 18$ \\
California Current Water. & CCW & $\leq 34.5$ & $12 \leq \mathrm{T} \leq 18$ \\
Subtropical Subsurface Water. & StSsW & $34.5<\mathrm{S}<35$ & $9 \leq \mathrm{T} \leq 18$ \\
Pacific Intermediate Water. & $\mathrm{PIW}$ & $34.5 \leq \mathrm{S}<34.8$ & $4 \leq \mathrm{T}<9$ \\
Deep Pacific Water. & DPW & $34.5<\mathrm{S} \leq 35$ & $0 \leq \mathrm{T} \leq 3$ \\
\hline
\end{tabular}


The aim of this work is to describe the hydrography of the entrance of the Gulf of California, in particular the limit with the $\mathrm{OMZ}$, as well as to understand how this water mass is directly influenced by mesoscale structures (eddies and currents) found in the region, altering its composition and features.

\section{Materials and Methods}

In this work, results from two groups are incorporated. Between 1991 and 2005, the oceanographyc cruises entitled PATO (acronym for Eastern Tropical Pacific in Spanish) were carried out at the entrance of the California Gulf with the aim of studying biology, hydrography and dynamics of an oligotrophic ocean. A. Trasviña from the Physical Oceanographic Department of CICESE was the main researcher of these expeditions, with the exception of the 2005 expedition whos PI was Helmut Maske from the Department of Biological Oceanography. The different cruises incorporated students from the CICESE, from the School of Marine Science of the UABC, from the School of Marine Sciences of the UCOL and the Universidad de Guadalajara. The first cruise to sail the distance between Cabo San Lucas, Isla Socorro and Cabo Corrientes (Figure 1) was that by Roden (1958).

From 2005 to 2009 the oceanographic cruises of the Oceanographic Program of West Mexico (PROCOMEX) were carried out to study dynamics, thermodynamics and primary production of the Mexican Coastal Current. PIS were researches from CICESE with $M$. Lavin as main researcher, along with collaborators from the Universidad de Colima. Figure 2 shows the track of these cruises. Its main approach was to document the effect of eddies and mesoscale fronts (50 to $200 \mathrm{~km}$ ) in an oligotrophic region and to measure biological and physical characteristics of the coastal currents.

The vertical profiles were collected by traditional casts with conductivity, temperature and pressure (CTD) pro- bes. Table 2 lists the dates of each cruise, instruments used and variables.

In all oceanographic campagins, vertical profiles of temperature and salinity were recorded. Some also with disolved oxygen profiles. Figure 1 shows the plans of the PATO and PROCOMEX cruises, used in this work. capié en la frontera donde colinda con el mínimo de oxígeno y a su vez comprender como estas masas de agua son directamente influenciadas por estructuras de mesoescala (remolinos, corrientes, frentes) que se encuentran en la región, alterando su composición y características.

\section{Materiales y Métodos}

En este trabajo se incorporan los resultados de dos grupos de expediciones. Entre 1991 y 2005 se realizaron los cruceros oceanográficos PATO (Pacífico Tropical Oriental) en la entrada al Golfo de California con el objetivo de estudiar la biología, hidrografía y dinámica de un océano oligotrófico. A. Trasviña del Departamento de Oceanografía Física del CICESE fue el investigador principal de estas expediciones, excepto en la de 2005 cuyo responsable fue Helmut Maske del Departamento de Oceanografía Biológica. Los distintos cruceros incorporaron estudiantes del CICESE, de la Facultad de Ciencias Marinas de la UABC, de la Facultad de Ciencias Marinas de la UCOL y de la Universidad de Guadalajara. Se planearon para navegar la distancia entre Cabo San Lucas, Isla Socorro y Cabo Corrientes (Figura 1), reportada por primera vez en Roden, (1958).

De 2005 a 2009 se llevaron a cabo los cruceros oceanográficos del Programa Oceanográfico del Occidente de México (PROCOMEX) con el fin de estudiar dinámica, termodinámica y producción primaria de la Corriente Costera Mexicana. En ésta participan investigadores del CICESE con M. Lavín como investigador principal y colaboradores del CICESE y de la Universidad de Colima. La Figura 2 muestra la trayectoria de estos cruceros. Su enfoque principal fue documentar el efecto de giros y frentes de mesoescala (50 a 200 km) en una región oligotrófica, así como medir características biológicas y físicas de las corrientes costeras.

Los perfiles verticales fueron colectados mediante lances tradicionales con sonda de conductividad, temperatura y presión (CTD). La Tabla 2 enlista las fechas de cada crucero, instrumento utilizado y variables medidas.

En todas las campañas oceanográficas se registraron los perfiles verticales de temperatura y salinidad. En algu- nos contamos además con perfiles de oxígeno disuelto. La Figura 1 muestra los planes de los cruceros PATO y PROCOMEX, utilizados en este trabajo. 
Table 2.

Cruises made with their respective dates, type of CTD used and obtained variables $(\mathrm{T}=$ temperature, $\mathrm{S}=$ Salinity, $\mathrm{DO}=$ Dissolved Oxygen)

Tabla 2.

Cruceros realizados con sus respectivas fechas, tipo de CTD utilizado y variables obtenidas ( $\mathrm{T}=$ temperatura, $\mathrm{S}=$ Salinidad, $\mathrm{OD}=$ Oxígeno disuelto)

\begin{tabular}{cccccc}
\hline CRUICERS & DATES & T & S & OD & CTD TYPES \\
\hline PATO 1 & May-1992 & X & X & & Smart CTD \\
PATO 2 & June-1993 & X & X & & Mark III \\
PATO 3 & February-1994 & X & X & & Mark III \\
PATO 5 & June-1998 & X & X & & Sea Bird SBE9 \\
PATO 6 & March-2005 & X & X & x & Sea Bird SBE9 \\
PROCOMEX-0506 & June-2005 & X & X & X & Sea Bird SBE-911 \\
PROCOMEX-0511 & November-2005 & X & X & x & Sea Bird SBE-911 \\
PROCOMEX-0608 & August-2006 & X & X & X & Sea Bird SBE-911 \\
PROCOMEX-0703 & March-2007 & X & X & x & Sea Bird SBE-911 \\
PROCOMEX-0911 & November-2011 & X & X & X & Sea Bird SBE-911 \\
\hline
\end{tabular}
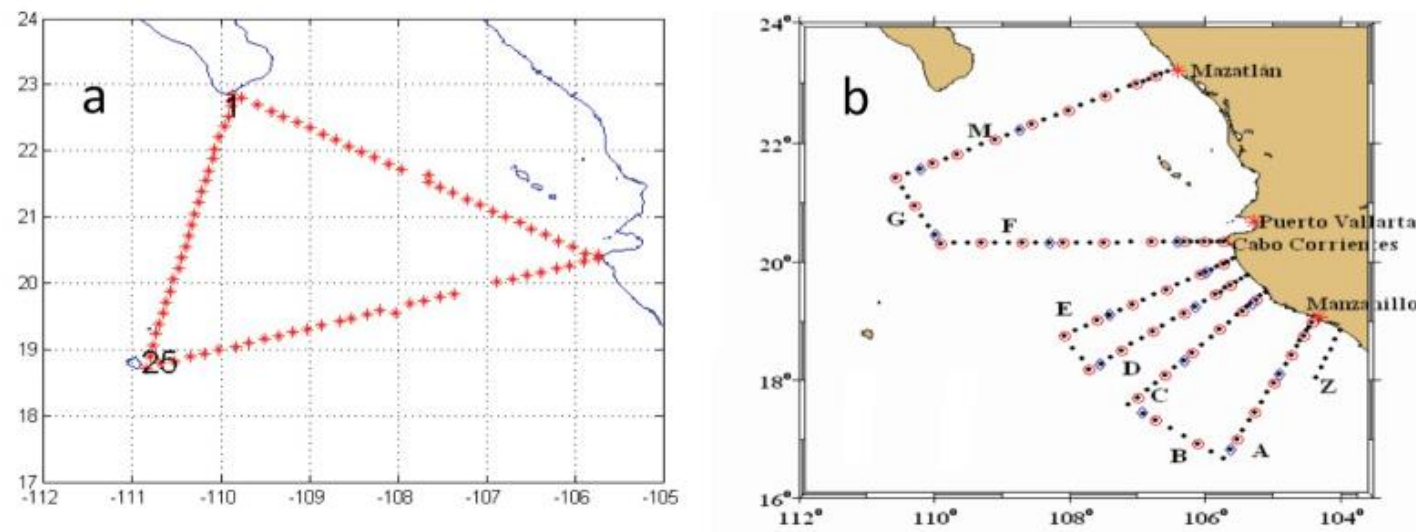

Figure 1. Geographic location of sampling stations. a) Cruise PATO 1. Red asteriks indicate sampling stations (1 indicates the beginning of the oceanographic campaign), b) PROCOMEX stations.

Figura 1. Ubicación geográfica de las estaciones de muestreo. a) crucero PATO 1. Los asteriscos rojos indican las estaciones de muestreo (1 indica el inicio de la campaña oceanográfica), b) Estaciones de PROCOMEX.

\section{Results and Discussion}

Seasonal and Space variation based in a TS diagram

We present the TS diagrams of all cruises, grouped by year, in the following figures. Each contains approxima-

\section{Resultados y Discusión}

Variación estacional y espacial en base a diagramas TS

En las siguientes figuras presentamos los diagramas TS de todos los cruceros, agrupados por esta- 
tely 90 vertical profiles per cruise and in some cases, there is more than one cruise per station. In the surface of the profiles $\left(T>15^{\circ} \mathrm{C}\right)$ a great variability along the year can be observed due to the confluence of multiple water masses in the entrance of the California Gulf (Table 1). These are the tropical surface water coming from the south (TSW), California Current water coming from its more southern extension (CCW) and the saline waters of the Gulf of California (GCW). Under the surface we found the subsuperficial subtropical water masses (StSsW) and the intermediate water masses (PIW) and depth from the Pacific (DPW).

In Figure 2, the great influence of the CCW under the surface in winter is highlighted, during February 1994, but also in March 2005 and 2007. The influence of the TSW is more ciones del año. Cada uno contiene aproximadamente 90 perfiles verticales por crucero y en algunos casos hay más de un crucero por estación. En la superficie de los perfiles $\left(T>15^{\circ} \mathrm{C}\right)$ se observa una gran variabilidad a lo largo del año debido a la confluencia de múltiples masas de agua en la entrada al Golfo de California (Tabla 1). Estas son el agua tropical superficial proveniente del sur (TSW), el agua de la Corriente de California proveniente de su extensión más sureña (CCW) y las aguas salinas del Golfo de California (GCW). Por debajo de la superficie encontramos las masas de agua subsuperficial subtropical (StSsW) y las masas de agua intermedia (PIW) y profunda del Pacífico (DPW).

En la Figura 2, destaca la gran influencia de la CCW bajo la superficie en invierno, durante febrero de 1994 pero tam-
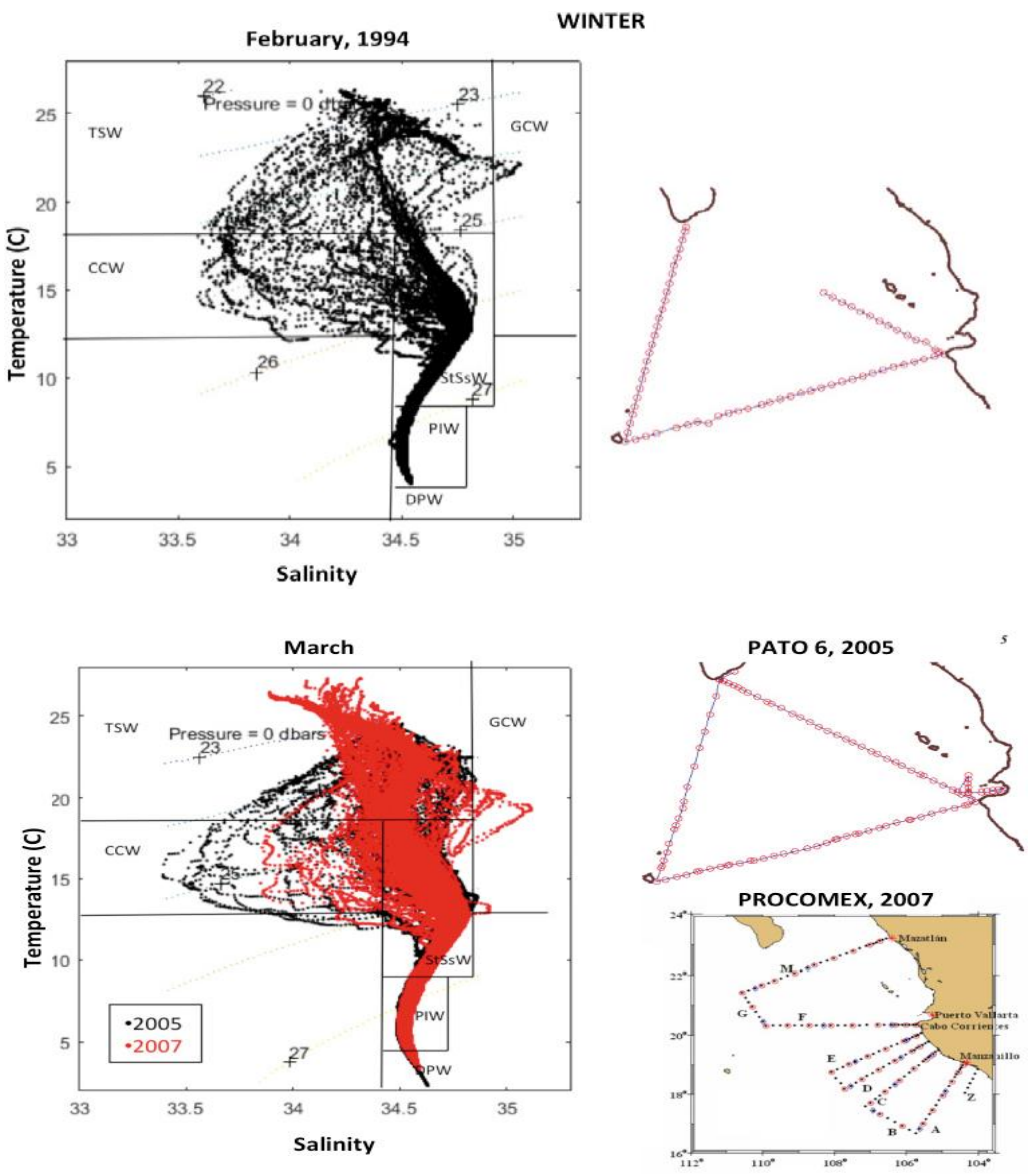

Figure 2. TS diagrams from the entrance to the Gulf of California in winter. Each graphic includes all profiles of the cruises, in different years and the study area. Above: cruise PATO 3; Below: PATO 6 and PROCOMEX 0703 (in red).

Figura 2. Diagramas TS de la entrada al Golfo de California en invierno. Cada gráfica incluye todos los perfiles de los cruceros, en años diferentes y el área de estudio. Arriba: crucero PATO 3; Abajo: PATO 6 y PROCOMEX 0703 (en rojo). 
important in March due to the more southern sections of the PROCOMEX 0703. This cruise almost reaches the $16^{\circ} \mathrm{N}$ in the transect in front of Manzanillo. Measurements within the Gulf of California in the cruise PROCOMEX reveal the influence of the GWC in the coastal region in front of Mazatlan, but not in the rest of the region. Under the isopycnal of $26 \mathrm{Kg} \mathrm{m}^{-3}$ the presence of the StSsW appears. The profiles of the PRCOMEX cruise are higher in number nearby the coast. In these, there is no CC water and the profiles describe a mixing line between the TSW and StSsW in the border with the OMZ (isopycnal of 26). This is a consequence of the disappearance of the influence of the CC towards the coastal zone. There is also a higher stratification than in the oceanic region here, hence many TS curves cut the isopycnals of the diagram in almost right-angle. In the cruise of 2007, few profiles (in red) reveal the presence of GCW near the surface, because it is the only cruise entering the Gulf of California.

Figure 3 contains vertical sections of temperature, salinity and frequency of stability during the cruise of February 1994 (PATO 3). Here, we use them to show the position of the water masses in the vertical column, and its stratification. During this cruise, the CCW is found under the surface in great part of the entrance to the Gulf. For example, in the line between Cabo San Lucas and Isla Socorro (LUSOC, Figures $3 \mathrm{a}$ and $3 \mathrm{~b}$ ) we discovered the presence of CCW that reveals the minimum subsuperficial of salinity. This occurs between 50 and $130 \mathrm{~m}$ depth and its found in almost all section. It is only interrupted at North of $21^{\circ} \mathrm{N}$ by an intrusion of warm $\left(>27^{\circ} \mathrm{C}\right)$ and saline (34.6) water that corresponds to TSW. The line between Isla Socorro and Cabo Corrientes (SOCCO, Figures $3 \mathrm{~b}$ and $3 \mathrm{e}$ ) also exhibits influence of the CCW between 50 and $130 \mathrm{~m}$ depth in its occidental extreme. Towards the center of the section, the minimum is more shallow $(80 \mathrm{~m})$ and towards the oriental extreme, in the coastal profiles in front of Cabo Corrientes, this water mass disappears to be substituted by tropical superficial water (TSW). The section between Cabo Corrientes and Cabo San Lucas was not completely covered (Figures $3 \mathrm{c}$ and $3 \mathrm{f}$ ), but the section that corresponds to the entrance to the Gulf of California, south from the Islas Marias, also shows the absence of CCW under the surface. The sections of stability frequency (in cycles per hour) show important changes in the stratification. The lower values of stratification occur in the LUSOC section (Figure $3 \mathrm{~g}$ ) where the CCW is more important. While in the coastal zone, where we only find two water masses in the column, the stratification shows more elevated values, for example, the bién en marzo de 2005 y 2007. La influencia de la TSW es más importante en marzo debido a las secciones más sureñas del PROCOMEX 0703. Este crucero casi alcanza los $16^{\circ} \mathrm{N}$ en el transecto frente a Manzanillo. Mediciones dentro del Golfo de California en el crucero PROCOMEX nos revelan la influencia de la GCW en la región costera frente a Mazatlán, pero no en el resto de la región. Por debajo de la isopicna de $26 \mathrm{Kg} \mathrm{m}^{-3}$ aparece la presencia de la StSsW. Los perfiles del crucero PROCOMEX son más numerosos cerca de la costa. En éstos no aparece el agua de la CC y los perfiles describen una línea de mezcla entre la TSW y StSsW en la frontera con la ZMO (isopicna de 26). Esto es una consecuencia de que la influencia de la CC desaparece hacia la zona costera. Aquí también hay una mayor estratificación que en la región oceánica, por esto muchas de las curvas TS cortan casi en ángulo recto las isopicnas del diagrama. En el crucero de 2007 unos pocos perfiles (en rojo) revelan la presencia de GCW cerca de la superficie porque es el único que entra al Golfo de California.

La Figura 3 contiene las secciones verticales de temperatura, salinidad y frecuencia de estabilidad durante el crucero de febrero de 1994 (PATO 3). Aquí los usamos para mostrar la posición de las masas de agua en la columna vertical, así como su estratificación. Durante este crucero la CCW se encuentra bajo la superficie en gran parte de la entrada al Golfo. Por ejemplo, en la línea entre Cabo San Lucas e Isla Socorro (LUSOC, Figuras 3a y 3d) descubrimos la presencia de CCW que revela el mínimo subsuperficial de salinidad. Este ocurre entre 50 y $130 \mathrm{~m}$ de profundidad y se encuentra en casi toda la sección. Solo es interrumpida al norte de $21^{\circ} \mathrm{N}$ por una intrusión de agua cálida ( $>27^{\circ}$ C) y salina (34.6) que corresponde a la TSW. La línea entre Isla Socorro y Cabo Corrientes (SOCCO, Figuras $3 b$ y $3 e$ ) también exhibe influencia de la CCW entre 50 y 130 m de profundidad en su extremo occidental. Hacia el centro de la sección el mínimo es más somero $(80 \mathrm{~m})$ y hacia el extremo oriental, en los perfiles costeros frente a Cabo Corrientes, esta masa de agua desaparece para ser sustituida por agua tropical superficial (TSW). La sección entre Cabo Corrientes y Cabo San Lucas no se recorrió completa (Figuras 3c y 3f), pero la sección que corresponde a la entrada al Golfo de California, al sur de las Islas Marías, también muestra la ausencia de CCW bajo la superficie. Las secciones de frecuencia de estabilidad (en ciclos por hora) muestran cambios importantes en la estratificación. Los valores más bajos de estratificación ocurren en la sección LUSOC (Figura 3g) donde la CCW es más importante. Mientras que la zona costera donde solo encontramos dos masas de agua en la columna, 
occidental extreme of the SOcCO section (Figure $3 \mathrm{~h}$ ) and the section CABOS (Figure 3i).

To summarize, the oceanic zone can have a weak stratification, compared with the one we measured closer to the coast, but the presence of the CCW interspersed between the surface and the superior border from the minimum oxygen makes the upwelling of the OMZ difficult. In the coast, the border of the OMZ is found very near the surface, but the intense vertical stratification makes the mix and the upwelling of the oxygen minimum difficult. Nevertheless, the OMZ can be very close to the surface, and in caso of an intense mixing process, perhaps induced by the wind, it would be capable to weaeken the stratification and drive to the surface waters of very low dissolved oxygen content. la estratificación muestra valores más elevados, por ejemplo el extremo occidental de la sección SOCCO (Figura 3h) y la sección CABOS (Figura 3i).

En resumen, la zona oceánica puede tener una estratificación débil, comparada con la que medimos más cerca de la costa, pero la presencia de la CCW intercalada entre la superficie y la frontera superior del mínimo de oxígeno, dificulta el afloramiento de la ZMO. En la costa, la frontera de la ZMO se encuentra muy cerca de la superficie pero la intensa estratificación vertical dificulta la mezcla y el afloramiento del mínimo de oxígeno. Sin embargo, en la costa la ZMO puede estar muy cerca de la superficie, y un proceso intenso de mezcla, quizás inducida por el viento, sería capaz de debilitar la estratificación y conducir al afloramiento de aguas de muy bajo contenido de oxígeno disuelto.
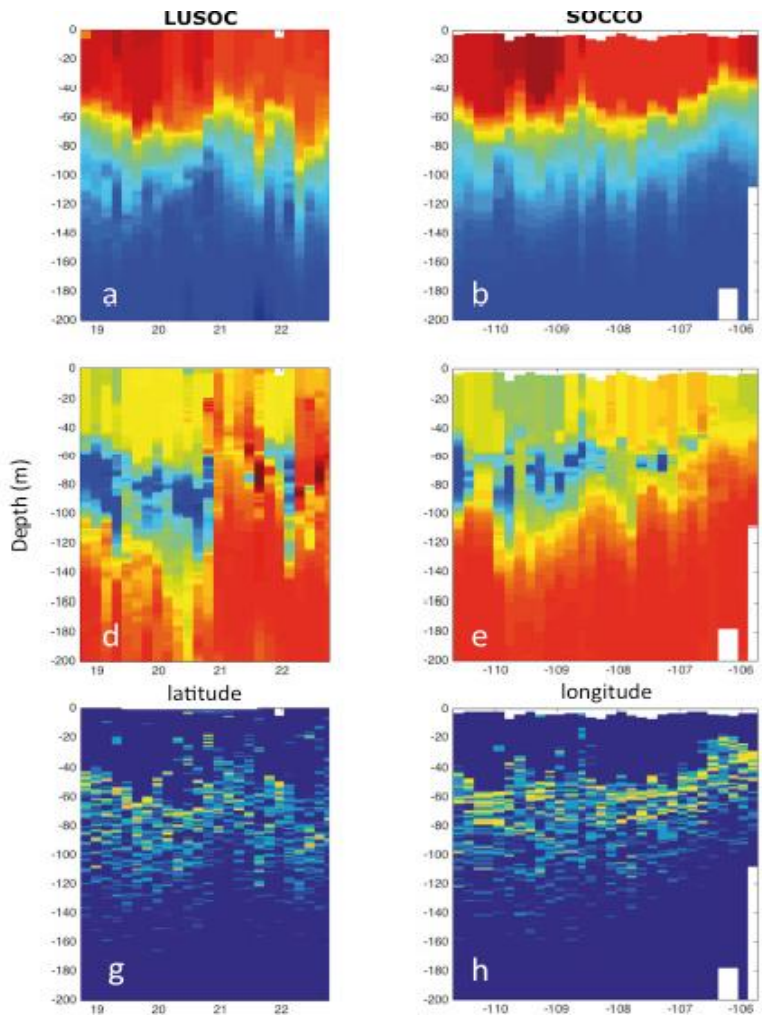
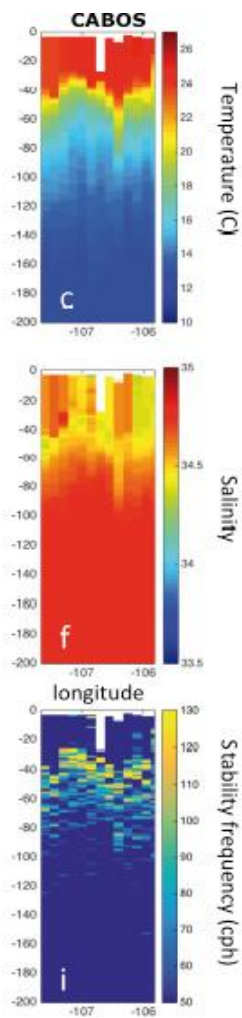

Figure 3. Cruise PATO 3. Vertical sections of temperature $\left({ }^{\circ} \mathrm{C}\right)$ in the lines a) LUSOC, b) SOCCO and c) CABOS; Salinity in the lines d) LUSOC, e) SOCCO and f) CABOS; and stability frequency (cph) in g) LUSOC, h) SOCCO e i) CABOS.

Figura 3. Crucero PATO 3. Secciones verticales de temperatura $\left({ }^{\circ} \mathrm{C}\right)$ en las líneas a) LUSOC, b) SOCCO y C) CABOS; de Salinidad en las líneas d) LUSOC, e) SOCCO y f) CABOS; y de frecuencia de estabilidad (cph) en g) LUSOC, h) SOCCO e i) CABOS. 


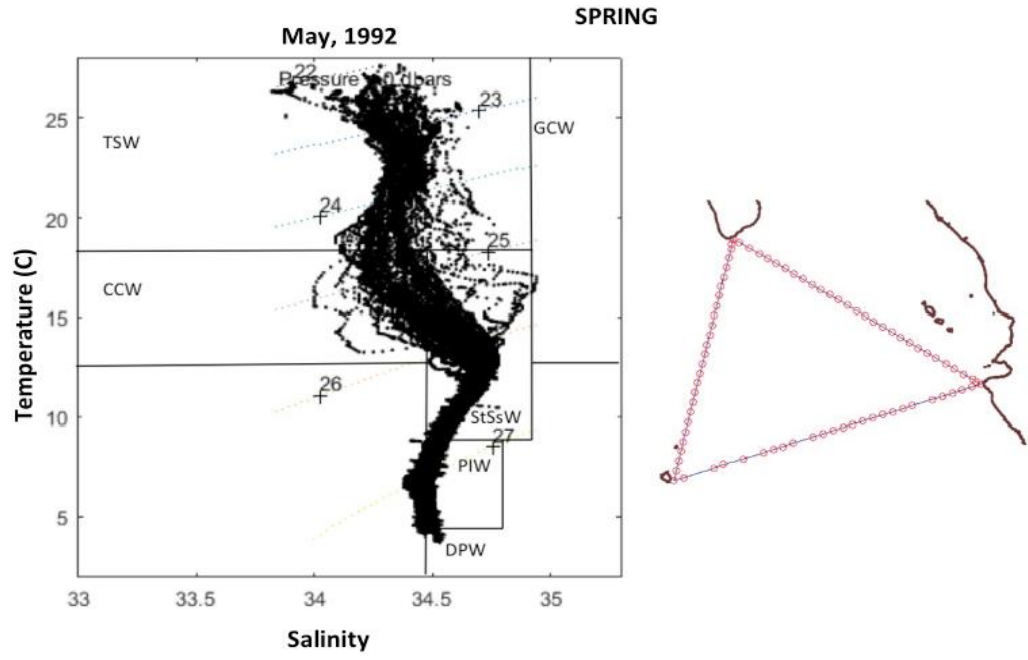

Figure 4. TS Diagram at the entrance of the Gulf of California (May, 1992), including all profiles of the cruise and the study area.

Figura 4. Diagrama TS de la entrada al Golfo de California en primavera (mayo, 1992), incluyendo todos los perfiles del crucero y el área de estudio.

In Spring (Figure 4) we only have the cruise of May 1992. The influence of TWS in the surface can be observed and there is presence of the water mass in the California $\mathrm{Cu}$ rrent (CCW), but it is not well differentiated as in winter and the minimum of salinity is of only 34 . The CCW is usually identified by a minimum of subsuperficial salinity of 33.5 to $50 \mathrm{~m}$ depth. In exchange, we found a mix version of the CCW inserted between the TSW the maximum subsuperficial of the StSsW. Neither is the Gulf water present (GCW). The vertical sections that are discussed in the next paragraph help to better understand these properties distribution. No differences between these coastal and oceanic stations can be noticed. In this spring, the stratification is very alike in all the entrance region.

Figure 5 contains the vertical sections of temperature, salinity and frequency of stability during the spring cruise (May 1992, PATO 1). The sections of temperature and salinity of the line LUSOC (Figures 5a and 5d) show an important slope in the northern half of the section. This is due to the influence of the CC in all entrance region. The salinity indicates its presence in the surface until more than $100 \mathrm{~m}$ depth. In the half north, the minimum of salinity is aligned with the thermocline. The section SOCCO (Figures 5b and $5 \mathrm{e}$ ) is also dominated by characteristics of the CCW of the surface at $140 \mathrm{~m}$ depth. Nevertheless, there are sites in the surface where tropical waters dominate, particu-
En la primavera (Figura 4) solo tenemos el crucero de mayo de 1992. Se observa la influencia de TSW en la superficie y hay presencia de la masa de agua de la Corriente de California (CCW), pero no esta bien diferenciada como en el invierno y el mínimo de salinidad es solo de 34. La CCW usualmente se identifica por un mínimo de salinidad subsuperficial de 33.5 a $50 \mathrm{~m}$ de profundidad. En su lugar encontramos una versión mezclada de la CCW insertada entre la TSW el máximo subsuperficial de la StSsW. Tampoco está presente el agua del Golfo (GCW). Las secciones verticales que se discuten en el párrafo siguiente ayudan a entender mejor esta distribución de propiedades. No se notan diferencias entre estaciones costeras y oceánicas. En esta primavera la estratificación es muy parecida en toda la región de la entrada.

La Figura 5 contiene las secciones verticales de temperatura, salinidad y frecuencia de estabilidad durante el crucero de primavera (mayo de 1992, PATO 1). La secciones de temperatura y salinidad de la línea LUSOC (Figuras 5a y $5 d)$ muestran una pendiente importante en la mitad norte de la sección. Esta se debe a la influencia de la CC en toda la región de la entrada. La salinidad indica su presencia de la superficie hasta más de $100 \mathrm{~m}$ de profundidad. En la mitad norte el mínimo de salinidad se alinea con la termoclina. La sección SOCCO (Figuras $5 b$ y $5 e$ ) también esta dominada por características de la CCW de la superficie a los $140 \mathrm{~m}$ de 
larly where there are maximums of temperature $\left(>28^{\circ}\right.$ C) and low salinities $(<34)$, for example, in the west of the section (Isla Socorro). This indicates that the characteristics that are observed in the surface of this cruise result, in great measure, from the mix between the CCW and the TSW and hence the TS diagram results atypical. In the east half of the line CABOS (Figures $5 \mathrm{c}$ and 5f) we observe a maximum of temperature and minimum salinity, consisting in the presence of TSW outside Cabo Corrientes. Here, a cold intrusion $\left(<20^{\circ} \mathrm{C}\right)$ with relatively high salinity $(>34.5)$ can be observed, which happens due to the upwelling of the StSsW until near the surface, within a structure consistent with the existence of an eddy of cold nucleus. West half presents a similar intrusion near Cabo San Lucas, but unlike the other sections, the surface is dominated by warm and saline waters. This cruise from spring 1992 contains information of an uncommon case. In these observations, the presence of the $\mathrm{CC}$ is unusual, it reaches great part of the entrance to the Gulf of California. The border of the StSsW and the OMZ is found away from the surface, except where the influence of eddies at mesoscale elevates the vertical structure. profundidad. Sin embargo hay sitios de la superficie donde las aguas tropicales dominan, en particular donde hay máximos de temperatura $\left(>28^{\circ} \mathrm{C}\right)$ y salinidades bajas $(<34)$, por ejemplo en el occidente de la sección (en Isla Socorro). Esto indica que las características que se observan en la superficie de este crucero resultan, en gran medida, de la mezcla entre la CCW y la TSW y por esto el diagrama TS resulta atípico. En la mitad oriental de la línea CABOS (Figuras 5 c y $5 f$ ) observamos un máximo de temperatura y mínimo de salinidad, consistente con la presencia de TSW afuera de Cabo Corrientes. Aquí también se observa una intrusión fría $\left(<20^{\circ} \mathrm{C}\right)$ y con salinidad relativamente alta (>34.5) que sucede por el afloramiento de la StSsW hasta cerca de la superficie, dentro de un estructura consistente con la existencia de un remolino de núcleo frío. La mitad occidental presenta una intrusión similar cerca de Cabo San Lucas, pero a diferencia de las otras secciones, la superficie esta dominada por aguas cálidas y salinas. Este crucero de la primavera de 1992 contiene información de un caso poco común. En estas observaciones la presencia de la CC es inusual alcanza gran parte de la entrada al Golfo de California. La frontera de la StSsW y de la ZMO se encuentra lejos de la superficie, excepto donde la influencia de remolinos de mesoescala eleva la estructura vertical.
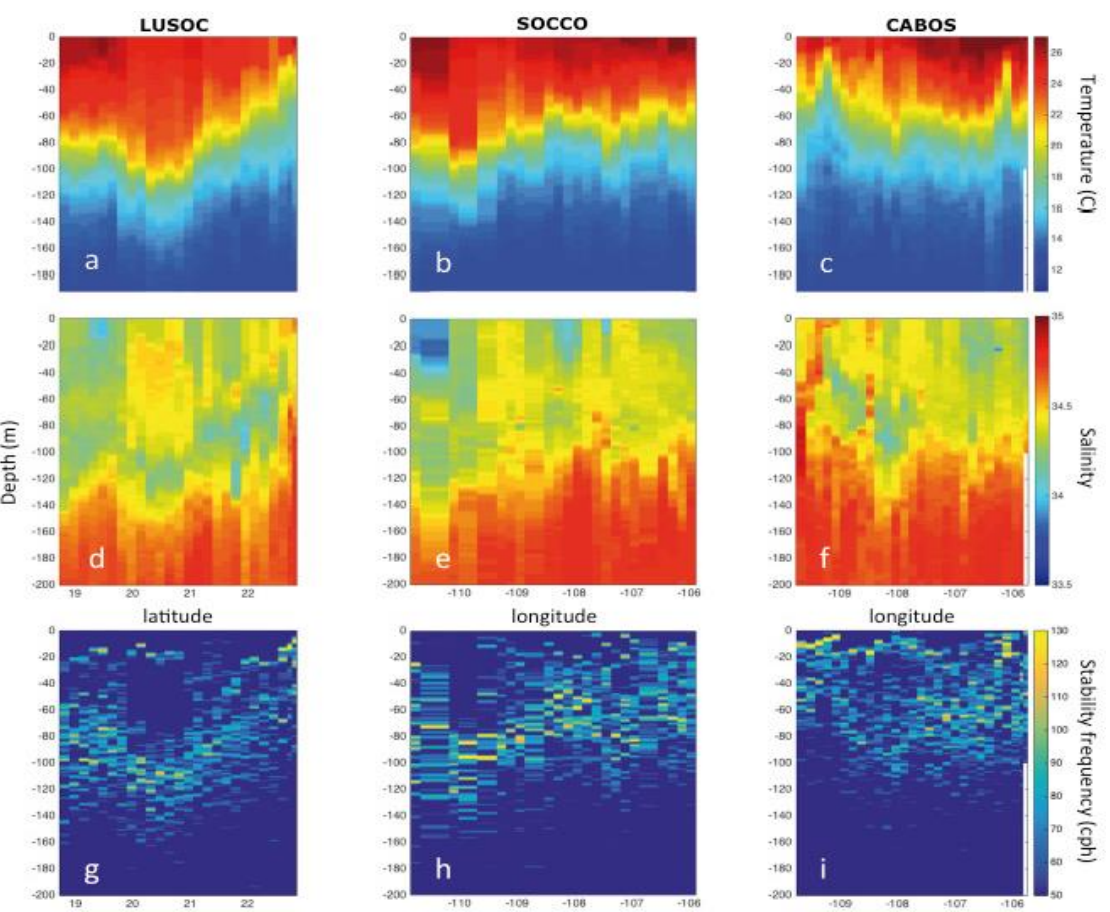

Figure 5. Cruise PATO 1. Vertical sections of temperature $\left({ }^{\circ} \mathrm{C}\right)$ in the lines a) LUSOC, b) SOCCO and c) CABOS; Salinity in the lines d) LUSOC, e) SOCCO and f) CABOS; and stability frequency (cph) en g) LUSOC, h) SOCCO

Figura 5. Crucero PATO 1 . Secciones verticales de temperatura $\left({ }^{\circ} \mathrm{C}\right)$ en las líneas a) LUSOC, b) SOCCO y c) CABOS; de Salinidad en las líneas d) LUSOC, e) SOCCO y f) CABOS; y de frecuencia de estabilidad 

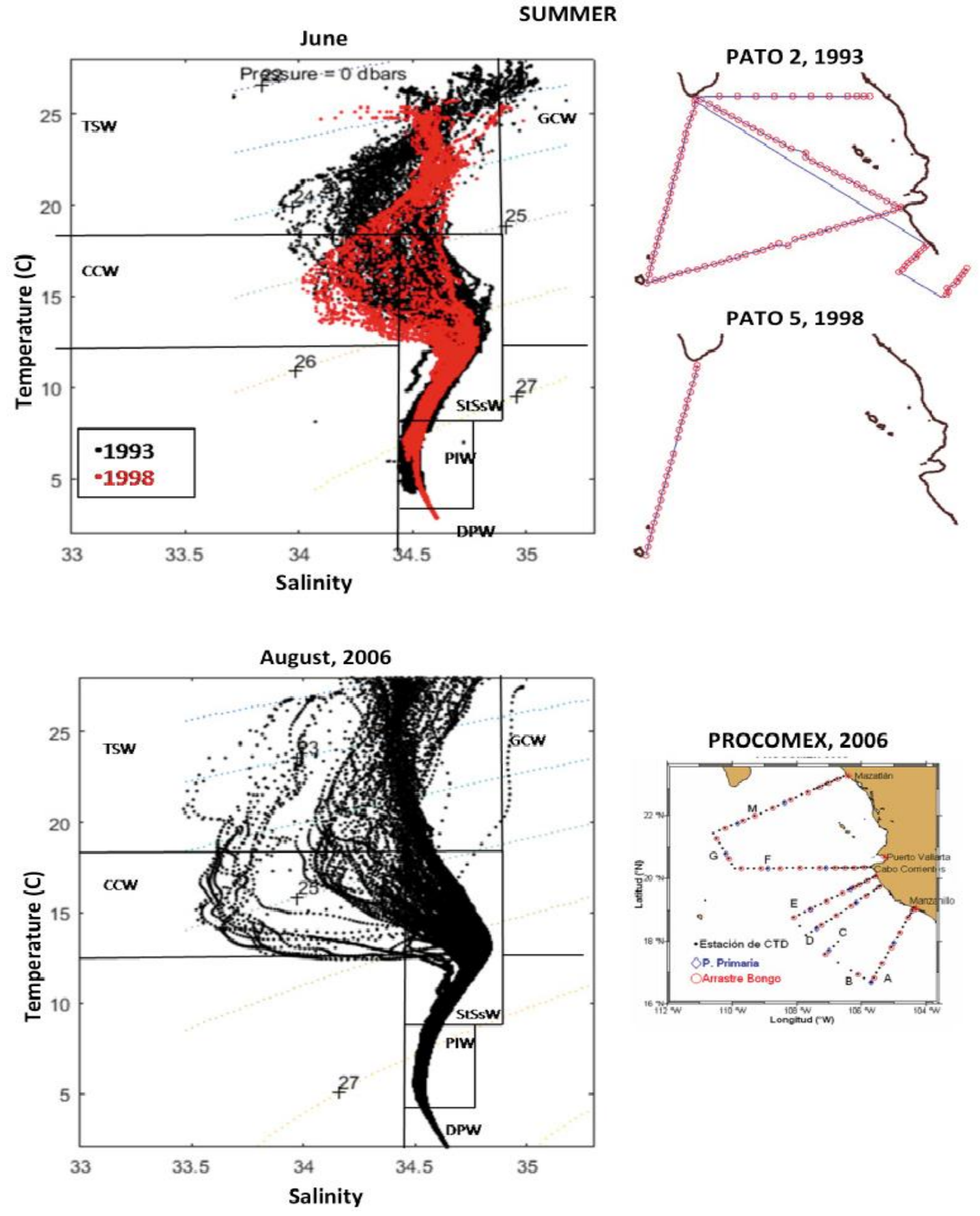

Figure 6. TS Diagrams of the entrance to the Gulf of California in the summer. Each graphic includes all profiles of the cruises, in different years and study areas. Above: cruises PATO 2, PATO 5 (in red) and PROCOMEX 0506 (in yellow); Below: PROCOMEX 0608.

Figura 6. Diagramas TS de la entrada al Golfo de California en verano. Cada gráfica incluye todos los perfiles de los cruceros, en años diferentes y el área de estudio. Arriba: cruceros PATO 2, PATO 5 (en rojo) y PROCOMEX 0506 (en amarillo); Abajo: PROCOMEX 0608. 
In summer (Figure 6), measurements within the gulf from June 1993 reveal the influence of GCW in the surface. Under the surface, the minimum of subsuperficial salinity that characterizes CCW can be observed, but more shallow (warm) than normal. The cruise from 1998 only contains data from the section between Cabo San Lucas and Isla Socorro, but presents the normal position of the minimum of the CCW in the region and this is evidence of significant interannual subsuperficial variability. The PROCOMEX cruise from August 2006 contains profiles towards south of the entrance and on the continental platform. There is higher presence here in the TSW surface due to coastal profiles between Manzanillo and Cabo Corrientes. Underneath the isopycnal of $26 \mathrm{Kg} \mathrm{m}^{-3}$ appears the presence of the StSsW in all profiles, but in coastal profiles there is no presence of the CCW. In these summers, there is a clear difference between the coastal and oceanic profiles. Near the coast, a mixing line connects the TSW directly with the StSsW (the border with the OMZ), while outside the coast, the CCW is intercalated between both water masses. Likewise, the oceanic zone contains two water masses above the $\mathrm{OMZ}$ and in the coast, only the TSW separates the StSsW (and the $\mathrm{OMZ}$ ) from the surface.

In the fall (Figure 7), there are two hydrographic PROCOMEX cruises that show the mixing line between TSW and StSsW in the southern and more coastal sections. This is clearer in the cruise of 2009, when only sections between Manzanillo and Cabo Corrientes were traveled. Measurements made in 2005 within the gulf contain the influence of GCW in the more superficial layer, but only in a few stations. In the cruise from 2005, the CCW appears again under the surface. A higher presence of the CCW is found here, because the transect from Cabo San Lucas to Isla Socorro was made in this cruise, where the extension of the California Current is present. Under the isopycnal of 26 , in the superior border of the OMZ, we found the presence of the StSsW. In this cruises we also observed a change between the coast and the oceanic zone. Near the coast, the profiles describe the line of mix between the superficial TSW and the StSsW, consistent with a higher stratification in all tropical and coast region. Here, the slope of the short mixing line cuts the isopycnals in an almost perpendicular way. In the oceanic region, the stratification is lower between the superficial layer and the sub-superficial waters lacking oxygen.
En el verano (Figura 6) las mediciones dentro del golfo de junio de 1993 revelan la influencia de GCW en la superficie. Bajo la superficie se observa el mínimo de salinidad subsuperficial que caracteriza a la CCW pero más somero (cálido) de lo normal. El crucero de 1998 solo contiene datos de la sección entre Cabo San Lucas e Isla Socorro pero presenta la posición normal del mínimo de la CCW en la región y esto es evidencia de variabilidad subsuperficial interanual significativa. El crucero PROCOMEX de agosto de 2006 contiene perfiles hacia el sur de la entrada y sobre la plataforma continental. Aquí hay mayor presencia en la superficie de TSW debido a los perfiles costeros entre Manzanillo y Cabo Corrientes. Por debajo de la isopicna de 26 $\mathrm{Kg} \mathrm{m}^{-3}$ aparece la presencia de la StSsW en todos los perfiles, pero en los perfiles costeros no se observa presencia de la CCW. Asimismo, en estos veranos hay una clara diferencia entre los perfiles costeros y los oceánicos. Cerca de la costa una línea de mezcla conecta la TSW directamente con StSsW (es decir con la frontera de la ZMO), mientras que afuera de la costa la CCW se intercala entre ambas masas de agua. Asimismo, en estos veranos la zona oceánica contiene dos masas de agua por arriba de la ZMO y en la costera solo la TSW separa a la StSsW (y a la ZMO) de la superficie.

En el otoño (Figura 7), hay dos cruceros hidrográficos PROCOMEX que muestran la línea de mezcla entre TSW y StSsW en las secciones más sureñas y más costeras. Esto es más claro en el crucero de 2009 cuando solo se recorrieron las secciones entre Manzanillo y Cabo Corrientes. Las mediciones hechas en 2005 dentro del golfo contienen la influencia de GCW en la capa más superficial, pero solo en unas cuantas estaciones. En el crucero de 2005 la CCW vuelve a aparecer bajo la superficie. Aquí se encuentra una mayor presencia de la CCW porque en este crucero se realizó el transecto de Cabo San Lucas a Isla Socorro donde está presente la extensión de la Corriente de California. Por debajo de la isopicna de 26, en la frontera superior de la ZMO, nos encontramos con la presencia de la StSsW. También en estos cruceros observamos un cambio entre la costa y la zona oceánica. Cerca de la costa los perfiles describen la línea de mezcla entre TSW superficial y la StSsW, consistente con una mayor estratificación en toda la región tropical y costera. Aquí la pendiente de la línea de mezcla corta las isopicnas de manera casi perpendicular. En la región oceánica la estratificación es menor y además tenemos la capa intermedia de la CCW que se intercala entre la capa superficial y la aguas sub-superficiales deficientes en oxígeno. 


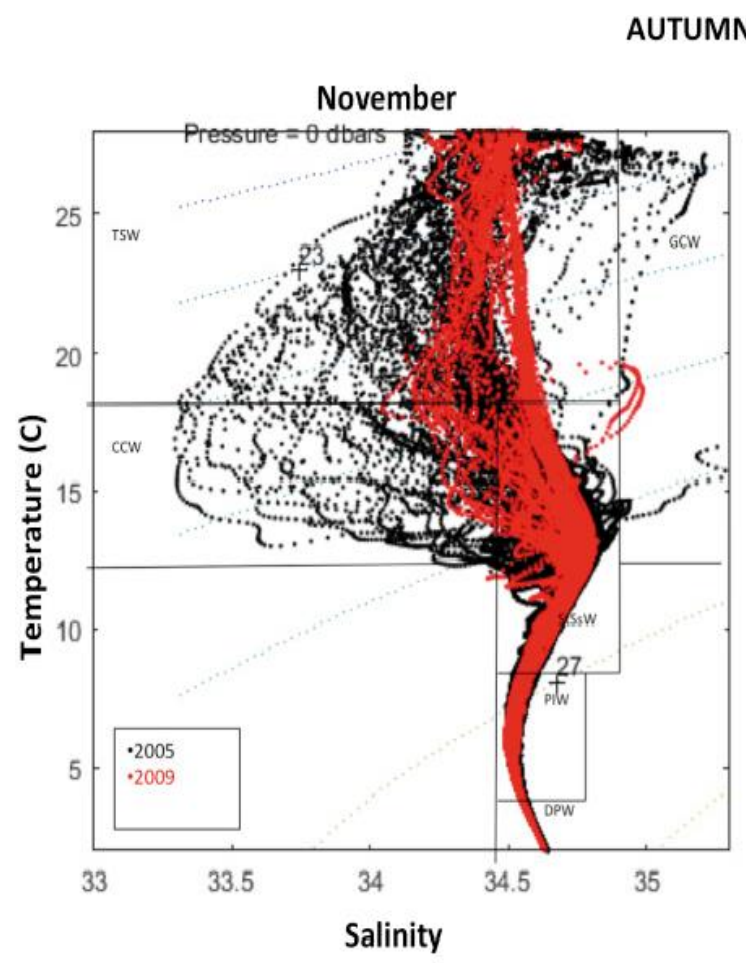

PROCOMEX, 2005

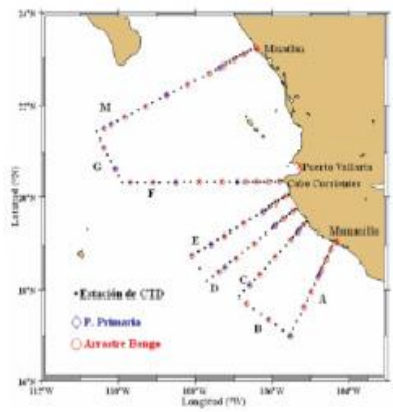

PROCOMEX, 2009

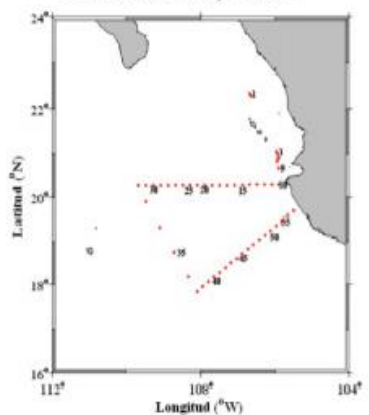

Figure 7. TS diagrams of the entrance to the Gulf of California in the fall. Each graphic includes all profiles from the cruises, in different years and study areas. Cruises: PROCOMEX 0511 and PROCOMEX 0911 (in red).

Figura 7. Diagramas TS de la entrada al Golfo de California en otoño. Cada gráfica incluye todos los perfiles de los cruceros, en años diferentes y el área de estudio. Cruceros: PROCOMEX 0511 y PROCOMEX 0911(en rojo).

\section{Influence of mesoscale structures}

To discuss the influence of mesoscale eddies we present hydrographic sections measured in the cruise of March 2005. In that time, profiles of temperature, salinity, chlorophyll fluorescence and dissolved oxygen were measured. We will argue this distributions in the three hydrographic transects between Cabo San Lucas and Isla Socorro (LUSOC), Isla Socorro and Cabo Corrientes (SOCCO) and de Cabo Corrientes to Cabo San Lucas (CABOS).

Figure 8 contains vertical sections of all variables in the LUSOC transect. In the temperature section (Figure $8 \mathrm{a})$ and between the latitudes 19 and $20.5^{\circ} \mathrm{N}$, the thermocline acquires the form of the cold nucleus dome, characteristic of an eddy of cyclonic rotation (counter-

\section{Influencia de las estructuras de mesoescala}

Para discutir la influencia de los remolinos de mesoescala presentamos secciones hidrográficas medidas en el crucero de marzo de 2005. En aquella ocasión se midieron perfiles de temperatura, salinidad, fluorescencia de clorofilas y oxígeno disuelto. Discutiremos estas distribuciones en las tres transectos hidrográficos entre Cabo San Lucas e Isla Socorro (LUSOC), Isla Socorro y Cabo Corrientes (SOCCO) y de Cabo Corrientes a Cabo San Lucas (CABOS).

La Figura 8 contiene las secciones verticales de todas las variables en el transecto LUSOC. En las sección de temperatura (Figura 8a) y entre las latitudes 19 y $20.5^{\circ} \mathrm{N}$, la termoclina adquiere la forma del domo de núcleo frío, característico de un remolino de rotación ciclónica (en contra de las manecillas del reloj). El frente térmico que delimita el 
clockwise). The thermal front that delimits the edge of the eddy ranges between 90 and $100 \mathrm{~m}$ depth, while its nucleus is found at $60 \mathrm{~m}$ in the core. Towards the north section, between 21 and $23^{\circ} \mathrm{N}$, the thermocline presents a slope to the coast, from about $120 \mathrm{~m}$ to less than $60 \mathrm{~m}$ in front of Cabo San Lucas. This is evidence of the presence of a geostrophic current that moves towards the east (into the interior of the Gulf) in the first $100 \mathrm{~m}$ of the water column. The section of salinity (Figure $8 b$ ) contains a nucleus of low salinity (33.3 - 33.7 ups) in the center of the eddy, consisting with its origin in the California Current (CC). In the north of the section, the shallow minimum of salinity (33.9-34.2 ups) corresponds to the coastal flux towards the east, and also confirms its origin in the CC. The section oxygen (Figure $8 c)$ contains an oxygenated region in the mix layer (4.1 a $5.1 \mathrm{mg} \mathrm{L}^{-1}$ ) over the oxycline, which coincides with the shape of the thermocline. Under the oxycline there is the OMZ. The hypoxic region exhibits values lower than $3 \mathrm{mg} \mathrm{L}^{-1}$ and often as low as $0.1 \mathrm{mg} \mathrm{L}^{-1}$ to $200 \mathrm{~m}$ depth or less. Again, in the interior of the eddy the characteristics are different to the surrounding environment. Within the eddy, the dissolved oxygen concentrations are $6 \mathrm{mg} \mathrm{L}^{-1}$ higher than the context, and its presence contributes to pushing the $\mathrm{OMZ}$ away from the surface. In the north extreme of the section, the coastal current also shows a higher concentration of dissolved oxygen. In the concentration section of chlorophyll (Figure 8d; JaimesHernández, 2006) we observe a subsuperficial layer where the concentrations of chlorophyll reached values 0.7 a $1.8 \mathrm{mg} / \mathrm{m}^{3}$. This is the maximum depth of chlorophyll (known as DMC) which stands here in the high part of the thermocline. This is an important zone because it is where the episodic fluxes of nutrients happen through the thermocline, induced by vertical mix processes (Sharples and Tett, 1994). A well-documented example are the intense pulses of wind from the Gulf of Tehuantepec that reach a shallow thermocline, weaken it and allow the vertical flow of properties towards the surface (Trasviña, 1991). The DMC follows closely the thermocline shape, its depth is related to the presence of mesoscale structures and currents, and it is located over the superior border of the OMZ. Towards the north of the transect, in the coastal current, the maximum signal of chlorophyll concentration of the transect was recorded, with ranges between 0.7 and $2.5 \mathrm{mg} / \mathrm{m}^{3}$. This is due to the input of the high productivity waters. The cyclonic eddy presents higher concentrations of chlorophyll in its northern border. borde del remolino oscila entre 90 y $100 \mathrm{~m}$ de profundidad, mientras que su núcleo se encuentra a $60 \mathrm{~m}$ en su centro. Hacia el norte de la sección, entre 21 y $23^{\circ} \mathrm{N}$, la termoclina presenta una pendiente hacia la costa, desde unos 120 $\mathrm{m}$ hasta menos de $60 \mathrm{~m}$ frente a Cabo San Lucas. Esta es evidencia de la presencia de una corriente geostrófica que avanza hacia el este (hacia el interior del Golfo) en los primeros $100 \mathrm{~m}$ de la columna de agua. La sección de salinidad (Figura 8b) contiene un núcleo de baja salinidad (33.3-33.7 ups) en el centro del remolino, consistente con su origen en la Corriente de California (CC). En el norte de la sección el mínimo somero de salinidad (33.9 -34.2 ups) corresponde al flujo costero hacia el este y también confirma su origen en la CC. La sección de oxígeno (Figura 8c) contiene una región oxigenada en la capa de mezcla (4.1 a $5.1 \mathrm{mg} \mathrm{L}^{-1}$ ) por encima de la oxiclina la cual, a su vez, coincide cercanamente con la forma de la termoclina. Debajo de la oxiclina se encuentra la ZMO. La región hipóxica exhibe valores menores a $3 \mathrm{mg} \mathrm{L}^{-1} \mathrm{y}$ a menudo tan bajos como $0.1 \mathrm{mg} \mathrm{L}^{-1}$ a $200 \mathrm{~m}$ de profundidad o menos. De nuevo en el interior del remolino las características son diferentes al medio circundante. Dentro del remolino las concentraciones de oxígeno disuelto son de $6 \mathrm{mg} \mathrm{L}^{-1}$, más elevadas que el entorno, y su presencia contribuye a alejar la ZMO de la superficie. En el extremo norte de la sección la corriente costera también muestra una concentración más alta de oxígeno disuelto. En la sección de concentración de clorofila (Figura 8d; Jaimes-Hernández, 2006) observamos una capa subsuperficial donde las concentraciones de clorofila alcanzan valores 0.7 a 1.8 $\mathrm{mg} / \mathrm{m}^{3}$. Este es el máximo profundo de clorofila (conocido como $D M C$ por sus siglas en inglés) que aquí reposa en la parte alta de la termoclina. Esta es una zona importante porque es donde suceden los flujos episódicos de nutrientes a través de la termoclina inducidos por procesos de mezcla vertical (Sharples y Tett, 1994). Un ejemplo bien documentado son los pulsos intensos de viento del Golfo de Tehuantepec que alcanzar una termoclina somera, la debilitan y permiten el flujo vertical de propiedades hacia la superficie (Trasviña, 1991). El DMC sigue cercanamente la forma de la termoclina, su profundidad está estrechamente relacionada a la presencia de estructuras de mesoescala y corrientes y se ubica sobre la frontera superior de la ZMO. Hacia el norte del transecto, en la corriente costera se registra la señal máxima de concentración de clorofilas del transecto, con rangos entre 0.7 y $2.5 \mathrm{mg} / \mathrm{m}^{3}$. Esto se debe al aporte de las aguas de alta productividad. El remolino ciclónico presenta concentraciones mayores de clorofila en su borde norte. 

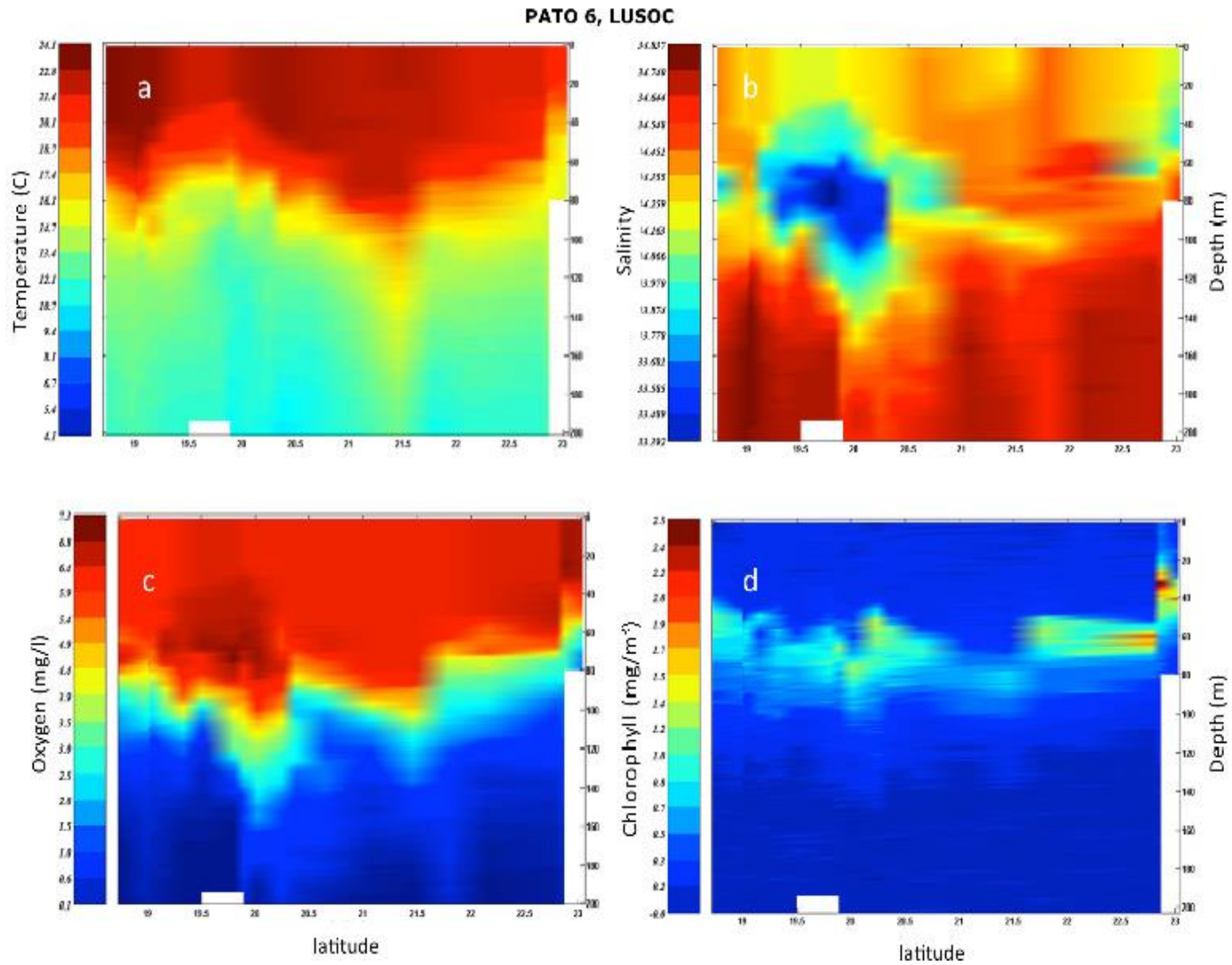

Figure 8. Vertical sections along the transect LUSOC of CTD in March 2005, within the oceanographic campaign PATO 6. The horizontal axis is latitude; the horizontal axis is depth, a) Temperature $\left({ }^{\circ} \mathrm{C}\right)$; b) Salinity (ups); c) Dissolved oxygen concentration $\left(\mathrm{mg} \mathrm{L}^{-1}\right)$, d) chlorophyll concentration $\left(\mathrm{mg} / \mathrm{m}^{3}\right)$.

Figura 8. Secciones verticales a lo largo del transecto LUSOC de CTD en marzo 2005, dentro de la campaña oceanográfica PATO 6. El eje horizontal es latitud; el eje vertical es la profundidad, a) Temperatura $\left({ }^{\circ} \mathrm{C}\right)$; b) Salinidad (ups); c) Concentración de oxígeno disuelto ( $\left.\mathrm{mg} \mathrm{L}^{-1}\right)$, d) Concentración de clorofila ( $\left.\mathrm{mg} / \mathrm{m}^{3}\right)$.

The sections of the CABOS line (Figure 9) initiate off Cabo San Lucas (to the left) and finish off Cabo Corrientes. In the temperature field we observe a thermocline between 50 and $100 \mathrm{~m}$ depth (Figure 9a). In the west of the section the thermocline decreases from Cabo San Lucas until $70 \mathrm{~m}$ in $109.5^{\circ} \mathrm{W}$. this is a coastal currents that flows to the interior of the Gulf of California. In the center of the section, at 109 to $107^{\circ} \mathrm{W}$ and along almost $200 \mathrm{~km}$, a dished thermocline under warm superficial eddy (anticyclonic) can be observed. Towards the east, between 107 and $106^{\circ} \mathrm{W}$, the thermocline is raised from $100 \mathrm{~m}$ to less than $50 \mathrm{~m}$ outside Cabo Corrientes. This slope is consistent with the existence of a superficial geostrophic flow leaving the gulf. The salinity section con-
Las secciones de la línea CABOS (Figura 9) inician frente a Cabo San Lucas (a la izquierda) y terminan frente a Cabo Corrientes. En el campo de temperatura observamos una termoclina entre 50 y $100 \mathrm{~m}$ de profundidad (Figura 9a). En el oeste de la sección la termoclina desciende desde Cabo San Lucas hasta $70 \mathrm{~m}$ en $109.5^{\circ} \mathrm{W}$. Esta es una corriente costera que fluye hacia el interior del Golfo de California. En el centro de la sección, de 109 a $107^{\circ} \mathrm{W}$ y a lo largo de casi $200 \mathrm{~km}$, se observa una termoclina cóncava bajo un remolino cálido superficial (anticiclónico). Hacia el este, entre 107 y $106^{\circ} \mathrm{W}$ la termoclina se eleva desde $100 \mathrm{~m}$ hasta menos de $50 \mathrm{~m}$ afuera de Cabo Corrientes. Esta pendiente es consistente con la existencia de un flujo geostrófico superficial saliendo del golfo. La sección de salinidad 
firms the flow tendencies (Figure 9b). The coastal currents of Cabo San Lucas is distinguished by a minimum (33.9 34.10) that is intensified under the surface and identifies its origin in the CC.

In all section of oxygen (Figure 9c) a superficial oxygenated region in the mix layer (4.6 to $4.9 \mathrm{~mL} \mathrm{~L}^{-1}$ ) above the oxycline can be observed. Under the oxycline the hypoxic region with values lower than $2 \mathrm{~mL} \mathrm{~L}^{-1}$ and as low as $0.1 \mathrm{~mL} \mathrm{~L}^{-1}$ to $200 \mathrm{~m}$ depth is found. A coastal current is also distinguished here, because it contains dissolved oxygen values higher than the environment. The input of cold water, low salinities and relatively high oxygen $(>4.9)$ within the coastal current continue to be consistent with their origin in the CC. The distribution of OD within the eddy is not symmetric, it contains low higher values in the oriental side of the eddy. In the oriental extreme of the transect, where the $\mathrm{OMZ}$ is more shallow $(20 \mathrm{~m})$, the oxycline is really close to the surface. In the fluorescence section (Figure 9d) we observe a subsuperficial layer with elevated values of until 0.027 volts. This correspond to the DMC that coincides with the base of the mixed layer. Towards the west of the transect, where the influence of the jet stream region in front of the coasts of Cabo San Lucas is located, the signal with higher values is recorded, between 0.020 and 0.027 volts. The water in this coastal current is rich in nutrients and so intensity of the DMC increases (Jaimes-Hernández, 2006). Towards the east, the DMC is found between the 40 and $60 \mathrm{~m}$, being more shallow in front of Cabo Corrientes. The depth variations of the maximum profound of chlorophylls are always linked with the presence of mesoscale structures.

The temperature section SOCCO (Figure 10a) is a zonal section that begins in Isla Socorro (left) and ends in Cabo Corrientes (right). In its occidental half, we found an eddy of warm nucleus, anticyclonic, while the rest of the transect to Cabo Corrientes present a thermocline horizontal at $60 \mathrm{~m}$ depth. In the salinity section (Figure 10b) the warm eddy contains a nucleus of low salinity (34.5-33.7 ups) from the surface to $120 \mathrm{~m}$ depth, which identifies it with the CCW. Towards east, the rest of the transect, temperatures and salinities correspond to TSW. The interior of the warm eddy contains the lower fluorescence values of chlorophylls in all the section (Figure 10d). unlike a cold eddy (see example Figure 9d), a warm eddy increases the thickness of the mixed superficial layer, which does not favor growth of phyto- confirma las tendencias del flujo (Figura 9b). La corriente costera de Cabo San Lucas se distingue por un mínimo (33.9 - 34.10) que se intensifica bajo la superficie e identifica su origen en la CC.

En toda la sección de oxígeno (Figura 9c) se observa una región oxigenada superficial en la capa de mezcla (4.6 a $4.9 \mathrm{~mL} \mathrm{~L}^{-1}$ ), por arriba de la oxiclina. Debajo de la oxiclina se encuentra la región hipóxica con valores menores a 2 $\mathrm{mL} \mathrm{L}^{-1} \mathrm{y}$ tan bajos como $0.1 \mathrm{~mL} \mathrm{~L}^{-1}$ a $200 \mathrm{~m}$ de profundidad. Aquí también se distingue la corriente costera porque contiene valores de oxígeno disuelto mayores que el entorno. El aporte de agua fría, salinidades bajas y oxígeno relativamente alto $(>4.9)$ dentro de la corriente costera siguen siendo consistentes con su origen en la CC. La distribución de OD dentro del remolino no es simétrica, contiene valores un poco mayores en el lado oriental del remolino. En el extremo oriental del transecto donde la ZMO es más somera $(20 \mathrm{~m})$ la oxiclina se acerca mucho a la superficie. En la sección de fluorescencia (Figura 9d) observamos una capa subsuperficial con valores elevados de hasta 0.027 volts. Estos corresponden al DMC que coincide con la base de la capa mezclada. Hacia el oeste del transecto, donde se ubica la región de influencia de la corriente de chorro frente a las costas de Cabo San Lucas, se registra la señal con valores más elevados, entre 0.020 y 0.027 volts. El agua en esta corriente costera es presumiblemente rica en nutrientes y por esto se incrementa la intensidad del DMC (Jaimes-Hernández, 2006). Hacia el este el DMC se encuentra entre los 40 y 60 m siendo más somero frente a Cabo Corrientes. Las variaciones de profundidad del máximo profundo de clorofilas están siempre ligadas con la presencia de estructuras demesoescala.

La sección de temperatura SOCCO (Figura 10a) es una sección zonal que inicia en Isla Socorro (izquierda) y acaba en Cabo Corrientes (derecha). En su mitad occidental encontramos un remolino de núcleo cálido, anticiclónico, mientras que el resto del transecto hasta Cabo Corrientes presenta una termoclina horizontal a $60 \mathrm{~m}$ de profundidad. En la sección de salinidad (Figura 10b) el remolino cálido contiene un núcleo de baja salinidad (34.5-33.7ups) desde la superficie hasta $120 \mathrm{~m}$ de profundidad que lo identifica con la CCW. Hacia el este, en el resto del transecto, las temperaturas y salinidades corresponden a TSW. El interior del remolino cálido contiene los valores más bajos de fluorescencia de clorofilas en toda la sección (Figura 10d). A diferencia de un remolino frío (ver por ejemplo Figura 9d) un remolino cálido incrementa el grosor de la capa mezclada superficial lo cual no favorece al crecimiento del fitoplancton en la DMC. En la sección 

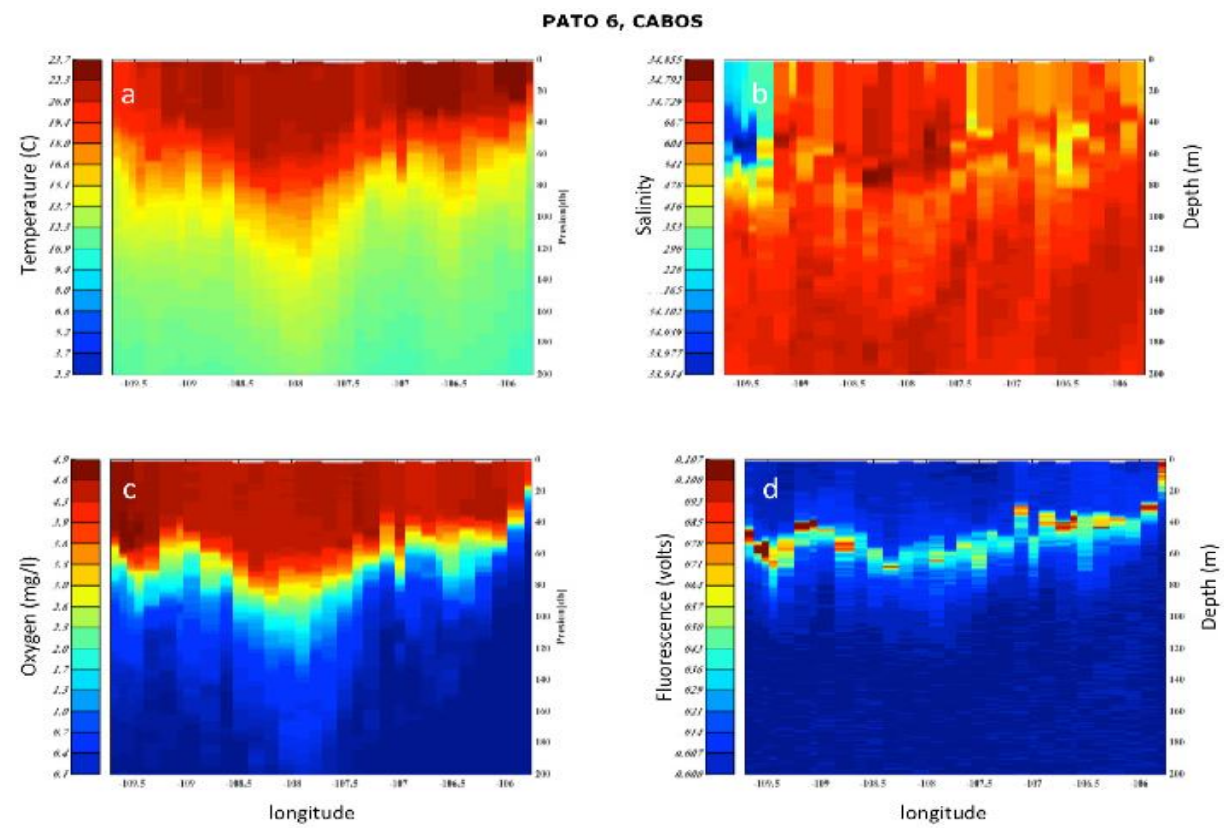

Figure 9. Vertical sections along the transect CABOS of CTD in march 2005, within the oceanographic campaign PATO 6. The horizontal axis shows length; the vertical axis shows depth, from the surface to $500 \mathrm{~m}$, Cabo San Lucas is located to the left and Cabo Corrientes in the left; a) Temperature ( $\left.{ }^{\circ} \mathrm{C}\right)$; b) Salinity (ups); c) Dissolved oxygen concentration ( $\left.\mathrm{mL} \mathrm{L}^{-1}\right)$; d) Fluorescence of chlorophyll (volts).

Figura 9. Secciones verticales a lo largo del transecto CABOS de CTD en marzo 2005, dentro de la campaña oceanográfica PATO 6. El eje horizontal muestra longitud; el eje vertical señala la profundidad desde superficie hasta $500 \mathrm{~m}$, Cabo San Lucas se ubica a izquierda y Cabo Corrientes a la izquierda; a) Temperatura ( $\left.{ }^{\circ} \mathrm{C}\right)$; b) Salinidad (ups); c) Concentración de oxígeno disuelto (mL L-1); d) Fluorescencia de clorofila (volts).

plankton in the DMC. In the oxygen section (Figure 9c), we have a high concentration region in the mixed layer ( 4.1 to $4.7 \mathrm{mg} \mathrm{L}^{-1}$ ) above oxycline that coincides with the shape of thermocline. The warm eddy contains high values of oxygen in the mix layer of its oriental side (from $109^{\circ}$ to $109.5^{\circ} \mathrm{W}$ ). Immediately underneath the oxycline, the hypoxic region that follows thermocline and sets the upper border of the OMZ is found. Oxyclines tends to be more shallow and reaches less than $50 \mathrm{~m}$ depth in the oriental extreme towards Cabo Corrientes. In the fluorescence section (Figure 10d), we observe a DMC with values of ranges of 0.008 and 0.019 that coincide with the base of the mixed layer. Towards Cabo Corrientes the maximal signal is recorded with ranges between 0.015 and 0.019 . The DMC is located between the 40 and $60 \mathrm{~m}$, being the most shallow in front of the coast of Cabo Corrientes. In addition, fluorescence maintains the maximum values (until 0.027 volts) in the DCM and closely follows thermocline shape. Here we de oxígeno (Figura 9c) tenemos una región de alta concentración en la capa de mezcla (4.1 a $4.7 \mathrm{mg} \mathrm{L}^{-1}$ ) por arriba de la oxiclina que coincide con la forma de la termoclina. El remolino cálido contiene valores altos de oxígeno en la capa mezclada de su flanco oriental (de $109^{\circ}$ a $109.5^{\circ} \mathrm{W}$ ). Inmediatamente por debajo de la oxiclina se encuentra una región hipóxica que sigue a la termoclina y marca la frontera superior de la ZMO. Hacia Cabo Corrientes la oxiclina tiende a ser más somera y alcanza menos de $50 \mathrm{~m}$ de profundidad en el extremo oriental. En la sección de fluorescencia (Figura 10d) observamos una DMC con valores de rangos de 0.008 y 0.019 , que coincide con la base de la capa mezclada. Hacia Cabo Corrientes se registran la señal máxima con rangos entre 0.015 y 0.019. La DMC lo ubicamos entre los 40 y 60 $\mathrm{m}$ siendo más somera frente a la costa de Cabo Corrientes. A su vez la fluorescencia mantiene valores máximos (hasta 0.027 volts) en el DCM y sigue cercanamente la forma de la termoclina. Aquí también observamos que su profundidad es influenciada por la presencia de estructuras de mesoescala. 

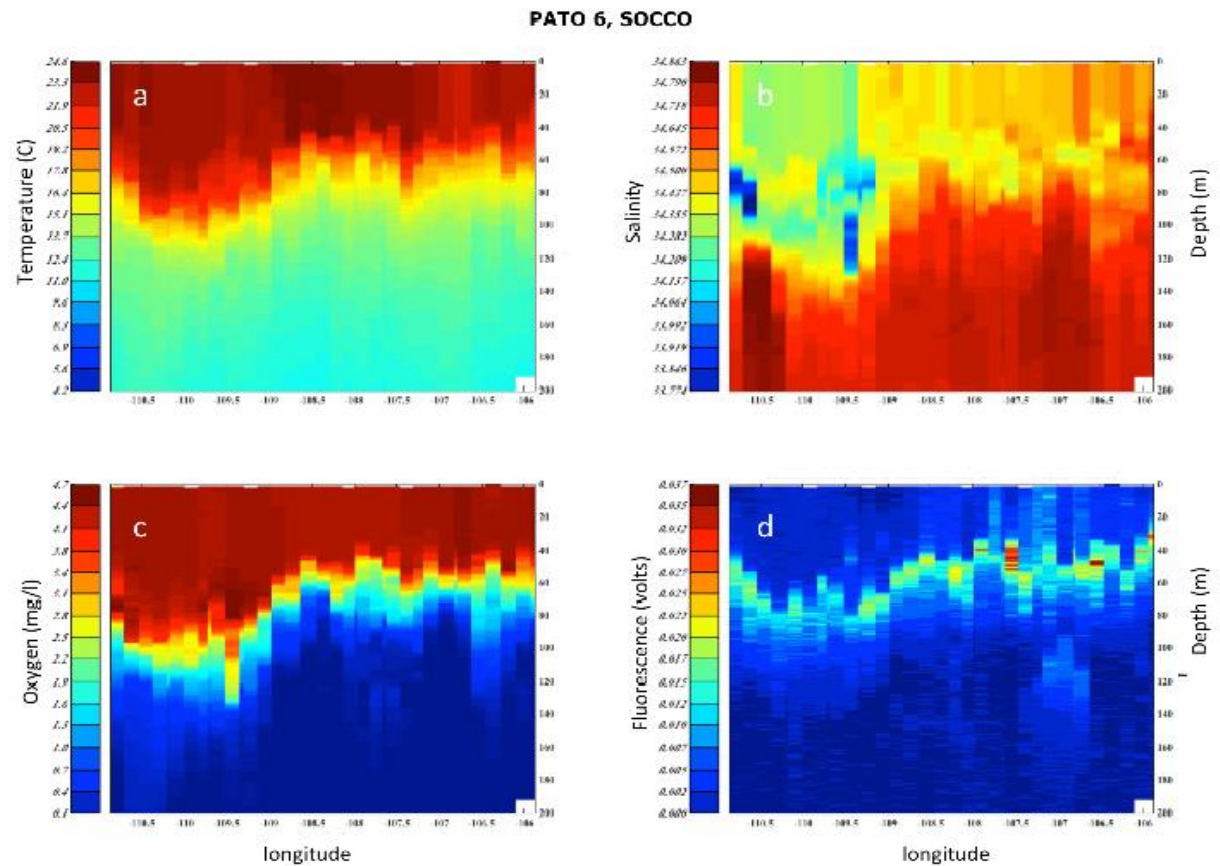

Figure 10. Vertical sections along the transect SOCCO of CTD in march 2005, within the oceanographic campaign PATO 6. The horizontal axis shows length; the vertical axis shows depth, from the surface to $500 \mathrm{~m}$, Isla Socorro is located to the left and Cabo Corrientes in the right; a) Temperature ( $\left.{ }^{\circ} \mathrm{C}\right)$; b) Salinity (ups); c) Dissolved oxygen concentration ( $\left.\mathrm{mL} \mathrm{L}^{-1}\right)$; d) Fluorescence of chlorophyll (volts).

Figura 10. Secciones verticales a lo largo del transecto SOCCO de CTD en marzo 2005, dentro de la campaña ocea nográfica PATO 6. El eje horizontal muestra longitud; el eje vertical señala la profundidad desde superficie hasta $500 \mathrm{~m}$, Isla Socorro se ubica a la izquierda y Cabo Corrientes a la derecha; a) Temperatura $\left({ }^{\circ} \mathrm{C}\right)$; b) Salinidad (ups); c) Concentración de oxígeno disuelto ( $\mathrm{mL} \mathrm{L}^{-1}$ ); d) Fluorescencia de clorofila (volts).

also observe that its depth is influenced by the presence of mesoscale structures.

The mesoscale structures are the most outstanding characteristics in the sections of March 2005. We have mesoscale eddies and fronts caused by coastal currents. In the LUSOC transect two structures appear. The first is a jet stream that directs to the interior of the Gulf of California. In front of the coast of the Baja California Sur peninsula. This current manifests as an intense subsuperficial flow with cold water, low salinity, characteristic of CC. The second structure is of higher size. This is a cold nucleus eddy of cyclonic circulation, located in the south extreme of the transect in front of the coast of Isla Socorro. The effect of both structures causes changes in depth of the maximum of chlorophylls and in the north side of the eddy a maximum in the concentration of chlorophylls appears. Cold eddies elevate
Las estructuras de mesoescala son las características más sobresalientes en las secciones de Marzo de 2005. Tenemos remolinos de mesoescala, así como frentes ocasionados por corrientes costeras. En el transecto LUSOC aparecen dos estructuras. La primera es una corriente de chorro que se dirige hacia el interior del Golfo de California frente a la costa de la península de Baja California Sur. Esta corriente se manifiesta como un flujo subsuperficial intenso con agua fría, de baja salinidad, característica de la CC. La segunda estructura es de mayor tamaño. Este es un remolino de núcleo frío de circulación ciclónica, ubicado en el extremo sur del transecto frente a la costa de Isla Socorro. El efecto de ambas estructuras ocasiona cambios en la profundidad del máximo de clorofilas y aparecen un máximo en la concentración de clorofilas en el flanco norte del remolino. Los remolinos fríos elevan la estructura vertical y estimulan la producción biológica. Estos remolinos elevan la estructura vertical y acercan el 
the vertical structure and stimulate biological production. These eddies elevate the vertical structure and get the nutrient supply close to the euphotic zone. This is important because high productivity cold waters tend to move with the eddy and convert into great chlorophyll patches (Miller, 2004). On the contrary, the warm eddy from the CABOS section increases the thickness of the mixed superficial layer, deepens DMC and measures the decrease of fluorescence of chlorophylls.

\section{Conclusions}

The water masses that come together at the entrance of the Gulf of California are enlisted in Table 1. Examining the observations, it is evident that some are more important than others in the entrance region. For example, the water mass of the Gulf of California (GCW) has no important presence. Only profiles made within the gulf, in the northern extreme of these routes, show some influence within the GCW. Water of the California Current is superficial, but often it is found under the Superficial Tropical. And Subsuperficial Subtropical is sometimes found so close from the surface that it could emerge and with it, the oxygen minimum.

Despite the scarceness of the observations, a seasonal cycle is revealed, characterized by a spring with strong influence of the California Current. In our spring cruise, a very thick superficial layer with evidence of mixing between CCW and TSW is observed. The stratification between the surface and the StSsW is weak, but the thickness of the superficial layer impedes it to emerge, except by influence of mesoscale eddies. The rest of the year, a different vertical sequence between the coastal region and the oceanic entrance can be observed. It is in the surface and immediately under it we find the StSsW and the OMZ. In the oceanic region we find the TSW in the surface, followed by the CCW centered at $50 \mathrm{~m}$ and below deepar than near the coast, the StSsW. Overall, stratification is more intense near the coast, which impedes the emerging of waters under oxygen content. This difference between the coastal and oceanic zone is larger in the summer cruises that were examined in this work

Nevertheless, there are other important processes. Near the coast, there is influence of sources related to coastal currents and in the oceanic region we find mesoscale eddies. Near the coast, the slope of the isopycnals associated to the coastal circulation is able to suministro de nutrientes a la zona eufótica. Esto es importante porque las aguas frías de alta productividad tienden a trasladarse con el remolino y se convierten en grandes parches de clorofila (Miller, 2004). Por el contrario, el remolino cálido de la sección CABOS incrementa el grosor de la capa mezclada superficial, profundiza el DMC y medimos un decremento de la fluorescencia de clorofilas.

\section{Conclusiones}

Las masas de agua que confluyen en la entrada al Golfo de California se enlistan en la Tabla 1. Examinando las observaciones es evidente que algunas son más importantes que otras en la región de la entrada. Por ejemplo la masa de agua del Golfo de California (GCW) no tiene una presencia importante. Solo los perfiles que se hicieron dentro del golfo, en el extremo norte de estos recorridos, muestran alguna influencia de la GCW. El agua de la Corriente de California es de origen superficial, pero aquí a menudo se le encuentra por debajo de la Tropical Superficial. Y el agua Subsuperficial Subtropical se encuentra en ocasiones tan cerca de la superficie que podría aflorar y, con ella, el mínimo de oxígeno.

A pesar de que las observaciones son escasas, se puede bosquejar un ciclo estacional, caracterizado por una primavera que tiene mucha influencia de la Corriente de California. En nuestro crucero de primavera se observa una capa superficial muy gruesa con evidencias de mezcla entre CCW y TSW. La estratificación entre la superficie y la StSsW es débil pero el grosor de la capa superficial impide que aflore, excepto por influencia de remolinos de mesoescala. El resto del año se observa una secuencia vertical distinta entre la región costera y la oceánica de la entrada. En la costa la TSW esta en la superficie e inmediatamente por debajo encontramos la StSsW y la zona del mínimo de oxígeno. En la región oceánica encontramos a la TSW en la superficie, seguida de la CCW centrada a $50 \mathrm{~m}$ y por debajo y a mayor profundidad que cerca de la costa, la StSsW. En general la estratificación es más intensa cerca de la costa, lo cual impide el afloramiento de aguas de bajo contenido de oxígeno. Esta diferencia entre la zona costera y oceánica es mayor en los cruceros de verano que examinamos en este trabajo.

Sin embargo, hay otros procesos importantes. En la costa hay influencia de frentes asociados a corrientes costeras y en la región oceánica encontramos remolinos de mesoescala. Cerca de la costa, la pendiente de las isopicnas asociada a la circulación costera es capaz de elevar el mínimo 
elevate the oxygen minimum very close to the surface, particularly off Cabo Corrientes, where the depth of the oxygen minimum is shallow. Offshore, cold eddies elevate the vertical structure and stimulate the biological production, but they also rise oxygen minimum close to the surface. On the contrary, warm eddies tend to increase thickness of the upper mixed layer, deepening and weakening the chlorophylls, and deepening the OMZ away from the surface.

This is a region where the influence of eddies alters the composition of the surface to generate by mixing water masses of intermediate characteristics. The presence of waters in the California Current within mesoscale eddies, between the surface and the subtropical subsuperficial water mass is able to generate ventilation of sub-superficial waters, and deepening the OMZ.

Finally, this work shows the importance of continuing hydrographic and currents monitoring in this region. We need to better understand the effect of the OMZ in the coastal communities to design mechanisms of adaptations to the changes that arise in a global warming scenario. de oxígeno muy cerca de la superficie, particularmente en la costa de Cabo Corrientes, donde la profundidad del mínimo de oxígeno es muy somera. Mar afuera los remolinos fríos elevan la estructura vertical y estimulan la producción biológica, pero acercan el mínimo de oxígeno a la superficie. Por el contrario, los remolinos cálidos tienden a incrementar el grosor de la capa mezclada superficial, profundizando y debilitando el máximo de clorofilas, y alejan el mínimo de oxígeno de la superficie.

Esta es una región donde la influencia de frentes y remolinos altera la composición de la superficie al grado de generar masas de agua de características intermedias, por mezcla. La presencia de aguas de la Corriente de California dentro de remolinos de mesoescala, entre la superficie y la masa de agua Subtropical Subsuperficial es capaz de generar ventilación de las aguas sub-superficiales y profundizar el mínimo de oxígeno.

Finalmente, este trabajo muestra la importancia de continuar el monitoreo hidrográfico y de corrientes en esta región. Necesitamos entender mejor el efecto del mínimo de oxígeno en las comunidades costeras para diseñar mecanismos de adaptación a los cambios que pueden surgir en este entorno de calentamiento global.

\section{References}

Álvarez-Sánchez, L.G., Stevenson, M.R., and Wyatt, B. 1978. Circulación y masas de agua en la región de la boca del Golfo de California en la primavera de 1970. Ciencias Marinas 5: 57-69. DOI: http://dx.doi.org/10.7773/cm.v5i1.314 http://www.cienciasmarinas.com.mx/index.php/cmarinas/article/view/314

Castro, R., Mascarenhas, A.S., Durazo, R. and Collins, C.A. 2000. Seasonal variation of the temperature and salinity at the entrance to the Gulf of California, Mexico. Ciencias Marinas 26: 561-583. DOI: http://dx.doi.org/10.7773/ cm.v26i4.621 http://www.cienciasmarinas.com.mx/index.php/cmarinas/article/view/621

Castro, R., Durazo, R., Mascarenhas, A., Collins, C.A. and Trasviña, A. 2006. Thermohaline variability and geostrophic circulation in the southern portion of the Gulf of California. Deep Sea Research Part I: Oceanographic Research Papers 53 (1): 188-200. DOI: doi.org/10.1016/j.dsr.2005.09.010 http://www.sciencedirect.com/science/article/ pii/S0967063705002360

Cepeda-Morales, J., Beier, E., Gaxiola-Castro, G., Lavín, M.F. and Godínez V.M. 2009. Effect of the oxygen mínimum zone on the second chlorophyll maximum in the Eastern Tropical Pacific off Mexico. Ciencias Marinas 35(4): $389-403$ http://www.scielo.org.mx/pdf/ciemar/v35n4/v35n4a6.pdf

Cepeda-Morales, J., Gaxiola-Castro, G., Beier, E. and Godínez, V.M. 2013. The mechanisms involved in defining the northern boundary of the shallow oxygen minimum zone in the eastern tropical Pacific Ocean off Mexico. Deep Sea Research Part I: Oceanographic Research Papers 76: 1-12. DOI: doi.org/10.1016/..dsr.2013.02.004 http://www.sciencedirect.com/science/article/pii/S0967063713000459

Diaz, R.J. and Rosenberg, R. 1995. Marine benthic hypoxia: a review of its ecological effects and the behavioural responses of benthic macrofauna. Oceanography and Marine Biology: an Annual Review 33: 245-303. http://www. emodnet-biology.eu/data-catalog?module=ref\&refid=234458\&printversion=1\&droplMIStitle=1

Griffiths, R.C. 1968. Physical, chemical, and biological oceanography of the entrance to the Gulf of California, spring of 1960. US Department of the Interior, Bureau of Commercial Fisheries 573: 47. http://spo.nmfs.noaa.gov/SSRF/SSRF573.pdf 
Helly, J.J. and Levin, L.A. 2004. Global distribution of naturally occurring marine hypoxia on continental margins. Deep Sea Research Part I: Oceanographic Research Papers 51(9): 1159-1168. DOI: doi.org/10.1016/i.dsr.2004.03.009 http://www.sciencedirect.com/science/article/pii/S0967063704000639

Hendrickx, M.E., and Serrano, D. 2010. Impacto de la zona de mínimo de oxígeno sobre los corredores pesqueros en el Pacífico mexicano. Interciencia: Revista de ciencia y tecnología de América 35(1): 12-18. http://www. redalyc. org/html/339/33913146003/

Jaimes-Hernández, A. 2006. Efecto de las estructuras hidrográficas de mesoescala en la distribución de los máximos subsuperficiales de clorofila y partículas, en la entrada al Golfo de California (Tesis de Maestría) La Paz: CIBNOR. http://dspace.cibnor.mx:8080/handle/123456789/138?show=full

Kessler, W.S. 2006. The circulation of the eastern tropical Pacific: A review. Progress in Oceanography 69: 181217. DOI: doi.org/10.1016/j.pocean.2006.03.009 http:/www.sciencedirect.com/science/article/pii/ S0079661106000310?via\%3Dihub

Lavín, M.F., Palacios-Hernández, E. and Cabrera, C. 2003. Sea surface temperature anomalies in the Gulf of Califor-nia. GEOFISICA INTERNACIONAL 42: 363-376. http://www.geofisica.unam.mx/unid apoyo/editorial/publicaciones/investigacion/geofisica internacional/anteriores/2003/03/lavin.pdf

Lavín, M.F., Beier, E., Gómez-Valdés, J., Godínez, V.M. and García, J. 2006. On the summer poleward coastal current off SW México. Geophysical Research Letters 33: 5-8. DOI: 10.1029/2005GL024686 http://onlinelibrary.wiley.com/ doi/10.1029/2005GL024686/pdf

Lavín, M.F., Castro, R., Beier, E., Godinez, V.M., Amador, A. and Guest, P. 2009. SST, thermohaline structure, and circulation in the southern gulf of California in June 2004 during the north American monsoon experiment. Journal of Geophysical Research: Oceans 114: 1-22. DOI: 10.1029 / 2008JC004896 http://onlinelibrary.wiley.com/ doi/10.1029/2008JC004896/abstract

Miller, C.M. 2004. Biological Oceanography. Malden, Massachussets, Blackwell Publishing, 402.

Portela, E., Beier, E., Barton, E.D., Castro, R., Godínez, V., Palacios-Hernández, E., et al. 2016. Water masses and circulation in the tropical Pacific off central Mexico and surrounding areas. Journal of Physical Oceanography. DOl: oi.org/10.1175/JPO-D-16-0068.1 http://journals.ametsoc.org/doi/10.1175/JPO-D-16-0068.1

Roden, G. 1958. Oceanographic and meteorological aspects of the Gulf of California. Pacific Science 12: 21-45. DOI: 10125/7874 https://scholarspace.manoa.hawaii.edu/handle/10125/7874

Serrano, D. and Hendrickx, M.E. 2011. Debajo de la zona del mínimo de oxígeno. Investigación y Ciencia: Edición Española de Scientific American 417: 13-15. http://www.investigacionyciencia.es/revistas/investigacion-y-ciencia/ la-inflacin-a-debate-528/debajo-de-la-zona-del-mnimo-de-oxgeno-8934

Sharples, J. and Tett, P. 1994. Modelling the effect of physical variability on the mid water chlorophyll maximum. Journal of Marine Research 52: 219-238. http://www.ingentaconnect.com/content/imr/jmr/1994/00000052/00000002/ art00003? crawler=true

Trasviña Castro, A. 1991. Offshore wind forcing in a coastal ocean: observations and modelling of the Gulf of Tehuantepec, Mexico (Doctoral dissertation). University College of North Wales.

Wyrtki, K. 1967. Circulation and water masses in the eastern equatorial Pacific Ocean. Int. Journal Oceanol. Limnol 1: 117-147.

Cite this paper/Como citar este artículo: Ruelas Tolentino, J.A., Trasviña Castro, A. (2017). Hydrography of the entrance to the Gulf of California hydrography: The upper limit of the oxygen minimum. Revista Bio Ciencias Revista Bio Ciencias 21 pages, Article ID: 04.05.02. http://dx.doi.org/10.15741/revbio.04.05.02 